\title{
Gender differences in customer expectations and perceptions of corporate social responsibility
}

\author{
Calabrese, Armando ; Costa, Roberta; Rosati, Francesco
}

Published in:

Journal of Cleaner Production

Link to article, DOI:

10.1016/j.jclepro.2015.12.100

Publication date:

2016

Document Version

Peer reviewed version

Link back to DTU Orbit

Citation (APA):

Calabrese, A., Costa, R., \& Rosati, F. (2016). Gender differences in customer expectations and perceptions of corporate social responsibility. Journal of Cleaner Production, 116, 135-149.

https://doi.org/10.1016/j.jclepro.2015.12.100

\section{General rights}

Copyright and moral rights for the publications made accessible in the public portal are retained by the authors and/or other copyright owners and it is a condition of accessing publications that users recognise and abide by the legal requirements associated with these rights.

- Users may download and print one copy of any publication from the public portal for the purpose of private study or research.

- You may not further distribute the material or use it for any profit-making activity or commercial gain

- You may freely distribute the URL identifying the publication in the public portal

If you believe that this document breaches copyright please contact us providing details, and we will remove access to the work immediately and investigate your claim 


\title{
Gender differences in customer expectations and perceptions of
}

\section{corporate social responsibility}

\author{
Armando Calabrese $e^{1,3}$, Roberta Costa ${ }^{1,3}$, Francesco Rosati $^{2,3^{*}}$ \\ ${ }^{1}$ Department of Enterprise Engineering, University of Rome “Tor Vergata”, Italy \\ ${ }^{2}$ Department of Management Engineering, Technical University of Denmark, Denmark \\ ${ }^{3}$ The authors contributed equally and are listed in alphabetical order \\ *corresponding author: frro@dtu.dk
}

\begin{abstract}
The literature on business ethics, corporate social responsibility and sustainability includes many studies on gender differences, however the results are often contrasting. In particular, there has not yet been full agreement on the role and significance of gender differences in customer expectations and perceptions of responsible corporate conduct. An extensive review of the research on the subject reveals that the published studies have not dealt with the substantive significance of gender differences, and as a result, the size of such differences is unknown. The current study analyses both the statistical and the substantive significance of gender differences in customer expectations and perceptions of corporate responsibility, also examining the influence of age and education. The analysis is carried out on a remarkably large sample of 908 clients, pertaining to 12 of the largest Italian banks. The overall results show that there is a small substantive difference between women's and men's average expectations, with women showing higher average values than men. This result holds generally true with variation of education levels and age groups. Young females show the highest average values of expectations, and the significance of gender differences decreases
\end{abstract}


with age. In contrast, the perception of corporate social responsibility does not show significant gender differences, either at the general level or when the analyses are repeated by education levels and age groups. The paper introduces the use of a standardized measure of effect size for analysing the substantive significance of gender differences in customer expectations and perceptions of corporate social responsibility. This novel approach increases results reliability and, accordingly, the effectiveness of company or policy maker strategies in designing, planning, implementing and assessing sustainability initiatives.

\section{Keywords}

Business ethics, corporate social responsibility (CSR), sustainability, gender differences, customer perceptions and expectations, effect size.

\section{Introduction}

Over recent decades it has been increasingly recognised that companies must behave responsibly, to respect the needs of current and future generations and preserve their rights to live in environments that are safe, healthy and rich with opportunity (WCED, 1987). To do this they must consider the impact of their productive activities on the social, environmental and economic dimensions in which they operate. Thus "companies should have in place a process to integrate social, environmental, ethical, and human rights concerns into their business operations and core strategy, in close collaboration with their stakeholders” (EC, 2011). Nevertheless some companies act irresponsibly, and so cause environmental and social harms (e.g. Sims and Brinkmann, 2003; Crooks, 2012). Given the contrasts among company behaviour and the simultaneous variety of offer in advanced economic systems, customers then have the opportunity to choose their purchases from those companies that operate in a sustainable manner (Seyfang, 2009). The enactment of this capacity implies that the 
customers are knowledgeable about the degree of responsibility of the companies of which they are stakeholders (Wigley, 2008; Lee and Shin, 2010).

Consequently, business ethics, CSR and sustainability are topics widely considered and discussed in the current business context. But what is the meaning of these concepts, and how are they related? Business ethics can be defined as "a form of applied ethics that examines ethical rules and principles within a commercial context” (Christensen et al., 2007, p. 351). CSR refers particularly to "the voluntary actions taken by a company to address economic, social and environmental impacts of its business operations and the concerns of its principal stakeholders” (Christensen et al., 2007, p. 351). Sustainability refers still more specifically to "business that contributes to an equitable and ecologically sustainable economy” (Christensen et al., 2007, p. 351). According to these definitions, business ethics refers to the general moral principles governing corporate decisions while the focus of CSR is on the decisions and actions concerning the specific area of stakeholder expectations. The areas of "business ethics" and "CSR" are then obviously closely related in the academic literature. In contrast, sustainability stands out as a distinct and highly important dimension of business ethics and CSR, with a specific focus on environmental aspects.

Although the literature suggests that the awareness of customers concerning company social and environmental responsibility has been increasing in recent decades (e.g. Brunk and Blümelhuber, 2011), not all customers are equally interested and knowledgeable about issues of responsible company behaviour (Elias, 2004; Lämsä et al., 2008). Customers’ expectations and perceptions about responsible conduct of companies can vary with their gender, education, age, ethnicity, culture, nationality and other characteristics (e.g. Luthar et al., 1997; Dellaportas, 2006). Among these, gender has attracted some of the most substantial scholarly attention. However, while the literature provides numerous studies on this issue, the results are often contrasting, and there is as yet no full agreement on the significance of gender 
differences in consumer expectations and perceptions of responsible corporate conduct (e.g. Collins, 2000; McCabe et al. 2006). Moreover, the existing literature on gender differences in business ethics, CSR and sustainability is affected by an extensive confusion of statistical significance with substantive significance.

As shown in more detail in section 2.3, statistical significance is about measurement precision and shows whether the observed values are distinguishable from chance; substantive significance is instead about the size of an effect and shows whether the magnitude of that effect is large enough to be considered relevant (Ellis, 2010). Thus a result concerning gender differences may be statistically significant, but not significant from the substantive point of view. Confusing these concepts can lead to systematic and misleading biases in scientific research (e.g., Ziliak \& McCloskey, 2008; Fine, 2010; Filippin \& Crosetto, 2014). One of the particular problems when studying gender differences is that the failure to attend substantive significance can cause the researcher to state that differences exist, without revealing their true relevance (size). Therefore, it is essential to report both statistical significance ( $\mathrm{P}$ value) and substantive significance (effect size).

Given this context, the current work examines the influence of gender differences on both CSR perceptions and expectations, in a particular commercial sector, while also deepening these explorations to reveal the gender-related influences with changing age and education, which are themselves known to be influential factors concerning responsible behaviour (e.g.; Luthar et al., 1997; Dellaportas, 2006; Lämsä et al., 2008). Moreover, the paper aims to clarify the difference between statistical significance and substantive significance of gender differences in business ethics, CSR and sustainability and review the literature accordingly. Thus the study analyses the substantive and statistical significance of the impact of gender differences on customer expectations and perceptions, and then repeats the comparison between men and women with different education levels and age groups, and then again for 
men and women concerning to different CSR issues and dimensions.

The analysis is carried out in the context of the Italian banking sector, examining the effect of gender differences among the clients of 12 major banks. Italy represents a useful field for research, as it is a world leader in the number of companies certified under sustainability standards, such as SA8000 (Ciliberti et al., 2008; Social Accountability Accreditation Services, 2015). The banking sector is particularly interesting as a research area because of a number of recent financial scandals. Such scandals have attracted widespread attention from the media, the general public, the bank customers, as well government institutions and scholars (Cosma and Gualandri, 2012). In fact, consumers in Italy and other nations often criticise the banking and financial sector for irresponsible behaviour, considering this as one of the causes of the current broader economic crisis. It is thus important and useful to understand customers' CSR expectations and perceptions for this area, which is fundamental and pervasive in all aspects of the economy, and which at the same time has been subject to heavy criticism (Fassin and Gosselin, 2011).

In the following section, the literature on the topic of gender differences in business ethics, CSR and sustainability is reviewed and discussed. Sections 3 and 4 present the research method and provide the results of the study. The final sections present the study discussion and conclusions.

\section{Literature Review}

Gender issues are of critical importance in the debate on orientation towards corporate responsibility (e.g. Larson and Freeman, 1997; Grosser and Moon, 2005; Grosser, 2009). This section reviews and discusses the literature concerning gender differences in perceptions, expectations and attitudes about ethics, business ethics, CSR and sustainability, with a special focus on substantive significance of gender differences. 
In a recent systematic literature review in areas (e.g. marketing, ethics, psychology) where gender differences are reliably observed, Meyers-Levy and Loken (2015) concluded that, in dealing with research comparing male and female, the term "sex" tends to be used in the biological sciences, whereas the term "gender" tends to be used in the social-psychological literatures. In the current article, the term "gender" is considered as synonymous with "sex" and does not refer to the social and cultural meaning of gender (e.g. gender roles and stereotypes). This choice is in keeping with previous studies concerning gender/sex differences in business ethics, CSR and sustainability, which tend to use the terms "sex" and "gender” interchangeably, referring to the male/female distinction as "gender” (e.g., Pérez and Rodríguez del Bosque, 2013; Lämsä et al., 2008; Luthar et al., 1997).

Table 1 provides a schematic summary of the ethics, business ethics, CSR and sustainability literature, showing the publications that inquire into the influence of gender on stakeholder perceptions, expectations and attitudes, in regards to company responsible efforts. This section concludes with a special focus on the difference between statistical and substantive significance of gender differences.

\section{[INSERT TABLE 1 ABOUT HERE]}

\subsection{Gender difference in ethics, business ethics, CSR and sustainability}

In recent decades, there has been a quite heated debate over if and how gender differences may influence consumer responses to company social and environmental responsibility (e.g., Pérez and Rodríguez del Bosque, 2013; Aouina Mejri and Bhatli, 2013).

According to the gender socialisation approach, gender can influence a person's moral orientation and the outcomes of their decisions and practices, since men and women will have 
different values and psychological characteristics. As early as 1972, Yankelovich conducted a series of studies on college students' personal and political attitudes, from which it emerged that males demonstrate more scepticism, cynicism and pessimism about the state of society and institutions than do females. According to these studies, women students are also more decisive than males "in their rejection of violence as a tactic or a philosophy" and show "a greater sense of commitment to doing things for others”.

Gilligan (1982) argued that from infancy, individuals will develop different ethical and behavioural models, depending on their gender. These models will continue to influence the individuals in their different social environments, through to adulthood. Gilligan states that in particular, men are more "justice oriented” in the face of moral dilemmas, meaning more inclined to take approaches and provide responses to dilemmas "conforming to the rules, laws and contracts for the sake of society” (Crandall et al., 1999). Women on the other hand will be more “care oriented”, meaning more inclined to approach moral dilemmas with empathy and comprehension.

In the late 1980s and early 1990s, a number of business ethics studies reported that women prefer and will adopt more ethical behaviours compared to men (e.g. Betz et al., 1989; Arlow, 1991; Borkowski and Ugras, 1992). According to Borkowski and Ugras (1992), males tend to be more utilitarian and more tentative and neutral in their approaches to business ethics, while in contrast females express more definite ethical positions than males. In regards to the work environment, Betz et al. (1989) held that men are more interested than women in the career opportunities offered by a company, while women place more importance on human relations and respect for principles of reciprocity. Ruegger and King (1992) stated that gender is a statistically significant factor influencing the ethical conduct of individuals, and that women are more ethical than males in their perception of business ethical situations.

A series of subsequent studies in business ethics reported that women are generally and 
situationally more ethically aware, sensitive and responsible than men (e.g. Deshpande et al., 2000; D’Aquila et al., 2004; Sigma-Mugan et al., 2005). Analogous conclusions were reached both in recent and less recent studies (e.g. Mason and Mudrack, 1996; Keith et al., 2009; Eweje and Brunton, 2010) and for different types of stakeholders, such as students (e.g. Smith and Oakley, 1997) and employees (e.g. Ekin and Tezolmez, 1999).

Besides, many authors have also stated that gender does not always influence the ethicality of business behaviour (McNichols and Zimmerer, 1985; Robin and Babin, 1997; Sankaran and Bui, 2003) and decision-making (Fritzsche, 1988; Roxas and Stoneback, 2004). Moreover, Derry (1989) argued that gender differences in the resolution of ethically related conflicts in the workplace may be context specific, and it is not always true that male moral reasoning is primarily based on a "morality of justice" and female reasoning is primarily based on a "morality of care”. Ford and Richardson (1994) reviewed 14 business ethics studies on the relationships between ethical perception and various individual characteristics, and found that seven of these studies stated gender had no impact on ethical decision making, while the other seven concluded that women were in fact more likely to act more ethically than men. Prasad et al. (1998) conducted their study on a sample of 191 US business students, with the objective of determining what constituted a "just society" in the opinions of the respondents, and what the differences in male and female expectations were. In response to a total of 51 statements, only 10 received statistically significantly different response from the two genders.

Hay et al. (2001), in analysing the effects of culture, gender and prior education on the students' perception of business ethics, found that the most statistically significant influence was the cultural background of the individual. Ergeneli and Arikan (2002) analysed the evaluation of different ethical scenarios by 248 salespeople, and found that there were no significant gender-related differences. Similarly, McCabe et al. (2006) conducted a study of 
224 undergraduate business students at a major American university and found that as an influencing factor, gender alone played no significant role in their ethical perceptions.

In CSR research, a variety of studies on gender differences again stated that women are more socially responsible than men (e.g. Marz et al., 2003; Lämsä et al., 2008; AlonsoAlmeida et al., 2015a). More specifically, Lämsä et al. (2008), in a study conducted on 217 economics students at a Finnish university, detected that females place more importance on the ethical, environmental and social responsibility of companies. Females were also observed as being more likely to follow a stakeholder model than a shareholder model. Similarly, Alonso-Almeida et al. (2015a) found that women place higher priority than men on CSR issues. Marz et al. (2003) again showed that female respondents express a higher social responsibility than male respondents. Alonso-Almeida (2013), in a recent study on the Spanish tourism sector, reported that female students place more importance on the social and environmental problems that a company must address. The same study also showed that women restaurant managers are more likely to adopt practices for energy and water saving. Aouina Mejri and Bhatli (2013), in a study of French customers of private labels, found that young and female clients are the most likely of all to show positive attitudes in response to socially responsible brands.

However, again in the CSR field, several authors have recently provided analyses that fail to detect significant gender differences in responsible orientation (Gholipour et al., 2012; Perez and Rodríguez del Bosque, 2013). For example Gholipour et al. (2012), in a study based on a sample of 320 business students in Iran, concluded that gender does not significantly impact on individual attitudes about CSR. Perez and Rodríguez del Bosque (2013), in a study of the Spanish banking sector, again observed that gender does not influence the process of the formation of CSR perceptions.

In another detailed analysis with still different conclusions on gender differences, Smith 
and Kumar (2013) examined CSR impact on employee organizational commitment and loyalty. Referring to the gaming industry, their evidence indicates that it is men that are more influenced by company CSR. In fact, the analysis shows that CSR initiatives have more effect on employee organizational commitment for male employees than for female ones.

Finally, studies on sustainability suggested that women customer are more likely than men to place more importance on sustainability than on the functional performance of products, as well as to express concern about the broader impacts of consumption and act upon those concerns (Luchs and Mooradian, 2012; Pomerici and Vecchio, 2012; Vicente-Molina et al., 2013). However, the literature on sustainability also again includes contrasting studies that observed few or no significant gender differences (e.g. Ng and Burke, 2010; Zhao et al., 2014). Wang et al. (2014) even found that women in rural Chinese areas are less active in participating in sustainable consumer behaviour and less concerned about environment than men. This result, according to the authors, is related to the higher education level of men in rural areas.

\subsection{Gender differences in stakeholders' perceptions, expectations and attitudes}

Many authors have studied the influence of gender on perceptions, expectations and attitudes about ethics, business ethics, CSR and sustainability (see Table 1). Among the first to study this specific topic was Arlow (1991), who analysed both the business ethics attitudes and the CSR perceptions and expectations of 138 American college students. The study considered five dimensions of social responsibility, including analyses of student expectations of "company contributions to society" and their perceptions of "corporate social efforts". In terms of gender differences, the study revealed that female students' expectations were statistically higher than male ones, but did not find there was any significant influence on perceptions of the CSR efforts achieved. 
Similarly Luthar et al. (1997) asked 691 business students "what the ethical climate is" (perceptions) and "what it should be" (expectations) in the business environment. This study found that gender is correlated to expectations, with female subjects showing more favourable attitudes towards ethical behaviours than males. However, once again the results did not show any significant influence of gender on the students’ perceptions of the business sphere. Prasad et al. (1998) analysed students' perceptions and expectations from a business ethics perspective, finding that out of 51 statements, only 10 received statistically significant different response from the two genders. Perez and Rodríguez del Bosque (2013) examined only gender influences on CSR perceptions, although they consider CSR expectations as a factor moderating the formation of such perceptions. Here the authors found that gender does not influence the process of forming CSR perceptions among Spanish customers of banking services. Shauki (2011) studied stakeholder perceptions and expectations of CSR disclosure practices in Indonesia, finding that females score higher than males in all the analysed factors, and especially concerning the importance of social and environmental reporting.

Other scholars considered only stakeholder perception of business ethics (e.g. McDaniel et al., 2001; Tsalikis et al., 2002; Atakan et al., 2008) or stakeholder perception of CSR (e.g. Elias, 2004; Panwar et al., 2010; Aouina Mejri and Bhatli, 2013), without taking into account expectations. On the contrary, Alonso-Almeida (2013) inquired into CSR stakeholder expectations, without considering perceptions.

Concerning stakeholder perceptions, Elias (2004) examined the effect of high-profile corporate bankruptcies on business students' perceptions of CSR. The results showed that female students have a higher perception than males regarding the importance of CSR, both before and after corporate scandals. Moreover, females are more likely to increase their perception of CSR importance after bankruptcies. In a similar line, Atakan et al. (2008) again found statistically significant indications that Turkish female students, in comparison with 
their male counterparts, have higher perceptions of the relevance of ethics in the business climate and in employee behaviour. Also, Aouina Mejri and Bhatli (2013) found that French female consumers are more perceptive than males to the communication of the "social quality” of private labels. On the contrary, Panwar et al. (2010), examining students' perceptions regarding social responsibility in the specific context of the US forest products industry, noticed that males are more satisfied with industries fulfilment of socioenvironmental responsibilities than are females. Also McDaniel et al. (2001) in a study of 1,982 employees of a US corporation found that males generally perceive a stronger ethical environment than females, regarding management concern for ethical issues and corporate ethical practices.

Concerning stakeholders' perceptions of business ethics, other studies have supported the findings of Luthar et al. (1997), in which no significant differences could be observed between the genders. An examination by Kidwell et al. (1987) observed that male and female managers do not differ in their perception of what is ethical and what is unethical. These authors also found that both genders view the opposite sex as more unethical than their own. Along similar lines, Tsalikis et al. (2002) examined stakeholders' ethical perceptions of two business scenarios involving immoral acts in Greece and the USA. They found that gender is not an important factor, while nationality has a statistically significant impact.

In the literature on stakeholder CSR expectations, Alonso-Almeida (2013) observed that female students have greater expectations than males that companies’ primary responsibilities should include consideration of social and environmental initiatives.

In addition to the focus on stakeholder expectations and perceptions of ethics, business ethics, CSR and sustainability, there is a larger body of literature that deals with the broader, or less well defined area, of general stakeholder "attitudes”. The scientific literature does not seem to provide an unequivocal indication on gender difference in stakeholder attitudes (e.g. 
Derry, 1989; Simga-Mugan et al., 2005; Lämsä et al., 2008). Instead the results are quite mixed, depending on the socio-cultural and geographic context of the studies and the different business functions studied, such as marketing, accounting, human resources or finance.

\subsection{The difference between statistical significance and substantive significance}

The existing literature on gender differences in business ethics, CSR and sustainability is typically hampered by confusion between statistical significance and substantive significance. It is important to emphasize that a statistically significant result may not be significant from the substantive point of view. Substantive significance investigates whether an observed effect is large enough to be relevant, while statistical significance can be detected also for very small effects that are too small to matter (Ellis, 2010). According with Ellis (2010), "statistical significance reflects the improbability of findings drawn from samples, given certain assumptions about the null hypothesis. Substantive significance is concerned with meaning, as in, what do the findings say about population effects themselves?” Therefore, while substantive significance refers to the size of a relationship or an effect, statistical significance refers only to precision in measurement (Sullivan and Feinn, 2012). In this regard, "effect size" is defined as "a quantitative reflection of the magnitude of some phenomenon that is used for the purpose of addressing a question of interest” (Kelley \& Preacher; 2012). Substantive significance informs about the size of a relationship or of an effect; in contrast, statistical significance informs about the confidence in the precision of the size of such a relationship or effect. For example, if the analysis of two different sustainability initiatives for the reduction of $\mathrm{CO}_{2}$ emissions finds results that are both "statistically significant”, but the first initiative reduces emissions by $1 \%$, while the second reduces them by $10 \%$, then the latter is more effective for environmental protection having greater “substantive significance”. For this reason, confusing these concepts can lead to systematic 
and dangerous biases in scientific research (Ziliak \& McCloskey, 2008) and, consequently, to biased management and policy decisions, as has been shown in psychology (Hyde, 2005; Fine, 2010), economics (Filippin \& Crosetto, 2014; Nelson, 2014) and many other different fields, from political sciences to medicine and pharmacology (Ziliak \& McCloskey, 2008).

Despite the importance of the topic, to the authors' knowledge, no studies have clarified the difference between statistical significance and substantive significance in the literature on gender differences in business ethics, CSR and sustainability. In most of the studies, only the statistical significance of gender differences is analysed, without considering the substantive significance (e.g. Luthar et al., 1997; Lämsä et al., 2008; Atakan et al., 2008).

Thus, this section aims to provide a useful theoretical and empirical contribution on this unexplored issue. In particular, it provides a detailed analysis of the results of the studies presented in sections 2.1 and 2.2, to see if the differences in the mean values are not only statistically significant, but also substantively significant. To compare across the different researches, this study uses Cohen's $d$, one of the most commonly applied measurements for effect size. Cohen's $d$ is defined as the difference between two means divided by a standard deviation for the data [1] (see Cohen, 1988), and is calculated as:

$$
d=\frac{\bar{X}_{1}-\bar{X}_{2}}{s_{p}}
$$

where $\bar{X}_{1}$ is the mean of the first group (women), $\bar{X}_{2}$ is the mean of the second group (men), and $s_{p}$ is the pooled standard deviation, a measure of the average within-group variation ${ }^{1}$. Cohen (1988, p. 40) defined the effect size of 0.2, 0.5, and 0.8 as small, medium, and large, respectively.

Table 2 summarizes the findings for women versus men concerning the publications surveyed in Table 1 for which data is available to calculate Cohen's $d$ : 17 articles are selected

\footnotetext{
${ }^{1} s_{p}$ is defined in [2] as:
}

$$
s_{p}=\sqrt{\frac{\left(n_{1}-1\right) s_{1}^{2}+\left(n_{2}-1\right) s_{2}^{2}}{n_{1}+n_{2}}}
$$

Where $s_{1}, s_{2}, n_{1}$, and $n_{2}$ are the standard deviations and sample sizes for the first and second group samples. 
and 19 variables analysed. For each study, the table reports: authors, publication year, Cohen's $d$ (calculated by the authors of this paper), type of study and sample size. A Cohen's $d$ greater (less) than 0 indicates that women show higher (lower) mean scores than men. In four cases, Cohen's $d$ has not been calculated, as the gender difference has not been found statistically significant (at a 10\% level or better).

\section{[INSERT TABLE 2 ABOUT HERE]}

This analysis suggests that, as regards CSR attitudes, substantive significance of gender differences varies among studies. In three cases (Mason and Mudrack, 1996; Lämsä et al., 2008; Alonso-Almeida et al., 2015a) authors claimed to have found statistically significant gender differences, and the analysis of substantive significance conducted in this paper shows small (Mason and Mudrack, 1996; Alonso-Almeida et al., 2015a) and medium (Lämsä et al., 2008) substantive differences between women’s and men’s average CSR attitudes. Moreover, this study finds that gender differences are not substantively significant in two other cases (Sankaran and Bui, 2003; Gholipour et al., 2012), in agreement with authors. Conflicting evidence emerge analysing six other studies, depending on the dimension and the indicator analysed (Smith and Oakley, 1997; Dawson, 1997; Burton and Hegarty, 1999; Deshpande et al., 2000; Ergeneli and Arikan, 2002; Sigma-Mugan et al., 2005).

Concerning perceptions, studying the articles of Luthar et al. (1997) and Perez and Rodriguez del Bosque (2013), substantive significant differences are not found, in agreement with authors' conclusions. In this regard, analysing the studies of Prasad et al. (1998), McDaniel et al. (2001) and McCabe et al. (2006), conflicting evidence depending on the indicators analysed emerge. The only two studies focused on expectations for which data is available are Luthar et al. (1997) and Prasad et al. (1998). Luthar et al. (1997) claimed to have 
found statistical significant gender differences in terms of expectations of what the ethical climate should be in the business environment. Nevertheless, the analysis of substantive significance shows that women have slightly higher average expectations than men (Cohen's $d=0.39)$. In the case of Prasad et al. (1998), instead, the analysis of substantive significance finds mostly non-significant gender differences, in agreement with authors' conclusions. However, on those items for which Prasad et al. (1998) found statistically significant gender differences, the calculation of average Cohen's $d$ is 0.40 , showing that, for those specific items, women have slightly higher average expectations than men.

In general, summarizing the above findings there has been no consensus in the literature on the substantive significance of gender differences in business ethics and CSR. Results often depend on the specific variables, dimensions and indicators analysed.

This analysis also shows the importance of the consideration of the substantive significance of gender differences. Considering only the statistical significance of results can be misleading, especially for those studies providing policy advice and guidance. Moreover, it could also lead to confirmation bias, potentially contributing to an increase in damaging gender stereotyping (Nelson, 2013a, 2013b; Jordan-Young, 2010). In particular, confirmation bias has been previously detected in gender differences literature (Nelson, 2013a). Confirmation bias is the bias towards interpreting new evidence as further confirmation of the researcher's existing beliefs or theories. In research on the topics of business ethics, CSR and sustainability, such biases might have influenced scholar to interpret their studies in a manner in keeping with existing beliefs and theories on gender differences. In order to increase awareness and knowledge of such bias and counter its effect, it is thus important that researchers consider not only the statistically significance, but also the substantive significance of their results.

The current study inserts in this substantial body of literature, providing deeper 
investigation of customer CSR expectations and perceptions, with particular reference to the Italian banking and financial services sector. The study analyses the influence of gender differences on customer CSR expectations and perceptions, deepening the analysis for different CSR dimensions and issues, and also considering different age groups and education levels. The primary reason for examining “customer” stakeholders in the banking sector is because, following the 2007-2008 financial crisis, bank customers have shown increasing concern about the importance of CSR in this particular sector. In addition, the sample size for the study is of notable dimension, lending more confidence to the study's conclusions on gender differences, in the area of CSR perceptions and expectations.

\section{Method and dataset}

\subsection{Method}

The current study uses the Global Reporting Initiative's Sustainability Reporting Guidelines (GRI, 2011) as the basis for assessing customer expectations and perceptions of CSR. The GRI is a widely accepted, structured framework for CSR reporting, subdivided under three sustainability dimensions, specifically: economic; environmental; social (Fernandez-Feijoo et al., 2014). The social dimension of sustainability is further divided in four sub-dimensions: labour practices and decent work; human rights; society; product responsibility. Each GRI dimension and sub-dimension is assessed by means of several indicators. The GRI guidelines are considered appropriate for CSR reporting regardless of the industrial sector and the company dimension (Marimon et al., 2012; Alan Willis, 2003).

The proposed method utilised the GRI indicators to create a series of "CSR issues", which are composed of individual indicators or groups of homogenous indicators (Bouten et al., 2009; Calabrese et al., 2013). The GRI indicators are grouped in “CSR issues” when they 
describe different characteristics of the same CSR topic. For example, as seen in Table 3, the CSR issue “waste”, under the GRI “environmental” dimension is reported by indicators EN22 and EN24, both describing waste reduction efforts of an organization.

The CSR issues selected for analysis are those most relevant to the banking sector. The selection of the relevant issues is done by means of content analysis technique, because it is widely proven as effective in the analysis of CSR report contents (Bouten et al., 2011; Striukova et al., 2008; Guthrie and Abeysekera, 2006). To reliably select the CSR issues through content analysis, the banks' sustainability reports were analysed by two or more expert coders, with the coding discrepancies between the coders subject to discussion, reanalysis and reconciliation (Lombard et al., 2002). The current study used four coders, whose expertise in CSR was assessed on the basis of their work or research experience in the specific field (i.e. they must be CSR managers and/or researchers). The intercoder reliability, calculated by the Krippendorff's alpha that synthesizes the coders' judgements, is $93.5 \%$ (Krippendorff, 2004). Since the intercoder reliability is greater than the threshold value of 80\% (Lombard et al., 2002; Neuendorf, 2002), the final selection of CSR issues (Table 3) is considered reliable.

\section{[INSERT TABLE 3 ABOUT HERE]}

For each of the selected CSR issues, customer judgments about CSR expectations and perceptions were collected by means of a structured questionnaire. As an example, the following are the questions posed to customers regarding the CSR issue "diversity and equal opportunity", corresponding to GRI indicators LA13 and LA14 under the "labour practices and decent work” social sub-dimension (Table 3):

- Question for assessing CSR expectations: "Considering the company under study, 
what are your expectations for this company's CSR commitment regarding equal opportunities in salaries and in composition of the workforce and governance bodies (equal opportunity regardless of gender, age, race, religion, etc.)?”. Customers were requested to answer using a five-point Likert scale: very low (1); low (2); fair (3); high (4); very high (5).

- Question for assessing CSR perceptions: "Considering the company under study, what is your perception of this company's CSR commitment regarding equal opportunities in salaries and in composition of the workforce and governance bodies (equal opportunity regardless of gender, age, race, religion, etc.)?”. Customers were requested to answer using the same five-point Likert scale.

Similar pairs of questions were developed for each of the CSR issues listed in Table 3 on the basis of the corresponding GRI indicators. The questionnaire was pre-tested on 25 bank customers in order to ensure clear understanding and avoid any vagueness. Wherever the customer responses and comments suggested a necessity, changes were made in the wording and sequencing of the questions.

\subsection{Dataset}

The 12 banks selected for inclusion in the current study are among Italy's largest in terms of stock capitalisation and quotation. The selection was also based on the fact that each of the 12 banks declares a commitment to CSR, as identified by the preparation of annual sustainability reports and the inclusion of "sustainability" sections on the company web sites. In addition, the authors also chose to include banks that participate in the "PattiChiari" (meaning “Transparent Agreements") initiative, a national CSR initiative coordinated by the Italian Banking Association in the last decade. Banks adhering to this initiative agree to 
objectives for improvement in company-customer relations, particularly in transferability of services, clarity of information, assistance and security for banking operations, and educating about more knowledgeable financial choices.

Between January and March 2013, the authors administered the questionnaire to 1,070 customers, selected randomly at locations inside and outside the branches of the 12 banks. Any questionnaires that were not completed in full were eliminated, thus resulting in a final sample of 908 customers (84.9\% of initial). Table 4 provides a description of the final sample in terms of three characteristics: customer gender, education level and age. Education level is described as “low, medium, high” and customer age as “<26 years, 26-35, 36-50, 51-65, and >65 years”, corresponding to young, younger adult, middle-aged, older adult and senior customers.

Of the 908 interview subjects included in the final sample, 433 were women $(47.7 \%$ of total) and 475 were men (52.3\%), which compares to the overall national population of $51.6 \%$ female and 48.4\% male (Istituto Nazionale di Statistica, 2013). Concerning education, 133 of the 908 subjects (14.7\%) had a low level, 378 (41.6\%) had a medium level of education, and 397 (43.7\%) had a high level (see Table 4 for definitions). The largest age category included was the 36 to 50 group (238 subjects, or $26.2 \%$ of total); the category least represented was that of individuals aged over 65 (100 subjects, $11.0 \%$ of total).

[INSERT TABLE 4 ABOUT HERE]

\section{Results and discussion}

The first subsection below presents the results from the general comparison between genders concerning their CSR expectations and perceptions, over the entire sample of subjects. The subsequent subsections deepen the analysis for the different education levels 
and age groups of the subjects, relative to the specific CSR dimensions, sub-dimensions and issues. The results of the current study are then compared with the results of gender difference literature on business ethics, CSR and sustainability, already discussed in Section 2.

\subsection{Overall results}

The general analysis (Table 5) shows that, in terms of CSR expectations, the female clients averagely express only slightly substantively significant higher judgements than do males (Cohen's $d=0.24$ ). This result is consistent with the findings of Luthar et al. (1997), for which it has been found a Cohen's $d=0.39$ (Table 2).

This analysis also distinguishes that for CSR perceptions, the overall results are not significant, thus it cannot be concluded that women perceive companies' CSR commitment any differently than do men (Table 5). This result agrees with the results of studies by Kidwell et al. (1987), Luthar et al. (1997) and Tsalikis et al. (2002).

These preliminary results thus confirm the importance of further scientific understanding of the dimensions of gender differences relative to CSR.

\section{[INSERT TABLE 5 ABOUT HERE]}

\subsection{Gender differences by education level}

As for the overall results, the analysis by the different levels of education (Table 6) shows that, concerning CSR expectations, there is a small substantive significance of gender differences, with the average judgements expressed by female clients slightly higher than those of males.

In particular, the analysis demonstrates that the differences between the average CSR expectations of men and women are substantively greatest where both genders have a lower 
level of education (Cohen's $d=0.37$ ), and tend to diminish or disappear with higher levels of education (Cohen's $d=\mathrm{NSS}$ ). Table 6 also shows that on average, individuals with higherlevel education have higher expectations than those with lesser levels of education. In the case of female customers, the difference between the average CSR expectations of high-educated respondents and those of low-educated ones is quite relevant (Cohen's $d=0.66$ ). In the case of male customers, this difference seems to be even stronger (Cohen's $d=1.02$ ). This result demonstrates that the customer's education level influences his or her expectations, with increasing education incrementing their sensitivity concerning CSR.

The results coincide with several preceding studies, which have likewise indicated that level of education influences respondents' attitudes toward responsible company conduct (e.g. Luthar et al., 1997; Gordon, 1998; Alonso-Almeida et al., 2015b). In particular, Kelley et al. (1990) demonstrate that individuals with higher university degrees show greater ethical orientation. Moreover, Sobczak et al. (2006) show that not only the educational level, but also the specific subject area of the individual's education influences their perceptions and attitudes toward CSR. In this vein, Elias (2004) shows that student education in business ethics and the stakeholder model has a positive influence on attitudes, awareness and general expectations for CSR. In contrast, business programs favouring the culture of profit maximization can actually contribute to decreasing the students' identification of importance for sustainability issues (Lämsä et al., 2008; Piper et al., 2012). For these reasons, universities must establish themselves as catalysts in favour of sustainability (Lozano, 2006; Lozano et al., 2013), by increasing their capacities in educating and training students to act as partners and leaders for sustainability initiatives (Manring, 2014; Waas et al., 2010).

As in the case of the overall results, the analysis of differences by education level shows that for CSR perceptions the results concerning gender differences are not statistically and substantively significant. Although these do not achieve significant levels regardless of the 
customer's education level, the gender differences are still seen to lessen as education progresses. The comparison of the average perceptions of high-educated male customers to those of low-educated male customers, reveals a Cohen's $d=0.52$. In the case of female customers, Cohen's $d$ is equal to 0.28 .

\section{[INSERT TABLE 6 ABOUT HERE]}

\subsection{Gender differences by age}

In the analyses conducted by different age groups of clients, the comparison of average CSR expectations for women and men shows a small substantive significance of gender differences, with average expectations higher for women, except in the case of customers above 65 years of age (Table 7). The highest differences are observed for clients under age 26 (Cohen's d=0.42), with the substantive significance of gender differences decreasing with age. In further detail, considering female customers, the comparison between the average CSR expectations of the clients under 26 years of age and those of the clients above age 65 does not show substantively significantly differences (Cohen's $d=N S S$ ). Conversely, in the case of male customers, these differences are more relevant (Cohen's $d=-0.33$ ), with customers above age 65 on average expecting more in terms of CSR performance than those under age 26. These results are consistent with those emerging in the studies by Dawson (1997) and Peterson et al. (2001), who report that ethical attitudes and beliefs develop at different age rates for each gender, with the maximum gender differences for younger people.

As found for the overall results and for the gender differences by education level, the results for CSR perceptions analysed by different age groups are mostly not substantively significant, so it cannot be concluded that women perceive companies' CSR commitment differently than men. As in the previous case, considering the comparison between clients 
under 26 years of age and those above age 65, the average CSR perceptions of female customers do not show substantively significant differences (Cohen's $d=\mathrm{NSS}$ ). This result is consistent with the study of Alonso-Almeida et al. (2015b), who do not find any direct and positive relationship between age and CSR perceptions of women managers. Conversely, in the case of male customers, these differences are more relevant (Cohen's $d=-0.41$ ), with customers above age 65 on average perceiving higher CSR efforts than those under age 26.

\section{[INSERT TABLE 7 ABOUT HERE]}

\subsection{Gender differences by CSR dimension}

The analysis for the different CSR dimensions shows that, concerning CSR expectations, gender differences appear to be of little significance and, in most of the cases, not very relevant (Table 8). The “environmental” dimension (EN) is the one where there is the greatest significance in gender differences (Cohen's $d=0.24$ ), followed by the “economic" dimension (EC) (Cohen's $d=0.20)$, and by the social sub-dimensions of "society” (SO) (Cohen's $d=0.19$ ) and "labour practices and decent work" (LA) (Cohen's $d=0.17)$. The differences for the other social sub-dimensions of "human rights” (HR) (Cohen’s $d=0.14)$ and "product responsibility" (PR) (Cohen's $d=0.12$ ) are lesser. The small but still relevant significance of gender differences as concerns average expectations about EN are in line with feminist environmentalism and eco-feminist theories (Agarwal, 1992; Perkins, 2007; O'Hara, 2009; Veuthey and Gerber, 2010). According to eco-feminist theories, women would typically be more concerned than men about balancing economic goals with the needs for environmental conservation, due to specific and significant connections between women and nature (Veuthey and Gerber, 2010). Some researchers have indeed found that women consistently behave in a more pro-environmental way than men (Davidson and Freudenburg, 1996; Zelezny et al., 
2000) and are more likely to carry out pro-environmental activities in both advanced and emerging countries (Vicente-Molina et al., 2013). It also seems more likely that women will engage in green consumer behaviour (Straughan and Roberts, 1999; Rex and Baumann, 2007).

The results obtained for CSR perceptions show that, in terms of substantive significance, gender differences do not appear very relevant, with the highest Cohen's $d=0.12$ found for EN dimension.

[INSERT TABLE 8 ABOUT HERE]

\subsection{Gender differences by CSR issue}

Concerning CSR expectations, the analyses by CSR issue (Table 9) show that gender differences are not very relevant, with only 3 out of 19 issues showing a Cohen's $d \geq 0.20$ (i.e. “indirect economic impacts”, “waste” and “diversity and equal opportunity”). Among these, the highest substantive significance is registered for the CSR issue of "diversity and equal opportunity” (Cohen's $d=0.23$ ). In this regard, following the interpretation of Prasad et al. (1998), less agreement between genders indicates a society with more discrimination between genders. This result is consistent with several studies which show the existence of a phenomenon of unequal opportunity in Italy (e.g. Peragine and Serlenga, 2008; Checchi and Peragine, 2010; Campus, 2010). The findings are further confirmed by the Global Gender Gap Report (World Economic Forum 2013), which classifies Italy in $71^{\text {st }}$ place for equal opportunity, out of the 133 nations considered, and among the last of the European nations. Considering the specific sub-indexes of "wage equality for similar work" and "labour force participation”, Italy places respectively in $124^{\text {th }}$ and $89^{\text {th }}$ place out of the 133 nations (World Economic Forum, 2013). Gender discrimination is a complex problem in all parts of the 
world, which must be solved in order to promote sustainable economic development. For this reason, it is of the utmost importance to investigate gender inequality through the CSR lens (Grosser and Moon, 2005, 2008).

\section{[INSERT TABLE 9 ABOUT HERE]}

Concerning CSR perceptions, the analysis by CSR issue shows that gender differences do not seem to be very relevant in terms of substantive significance, with the highest value of Cohen's $d=0.19$, registered in the case of the "materials" CSR issue of the environmental dimension (Table 10). The second highest value is registered for the CSR issue of "training and education” (Cohen's $d=-0.18$ ), with male customers on average demonstrating a small but substantively significantly higher perception, since it is men that would be more interested than women in the career possibilities offered by the companies to their employees (Betz et al., 1989).

\section{[INSERT TABLE 10 ABOUT HERE]}

\section{Discussion}

The overall results of this study show that female clients express expectation small but substantively significant higher than males, regarding commitment to CSR efforts on the part of the banks analysed. When the analysis is repeated for clients grouped by different education levels, these results do not generally vary between low-educated and mediumeducated customers, and becomes not substantively significant for high-educated ones. Both

genders share the common trait of substantively significant increase in their level of 
expectations with increasing education, thus showing greater sensitivity to CSR. Another relevant result is that as level of education increases, there is a decrease in the influence of gender differences. Concerning the analyses by age group, female clients consistently desire a small and substantively significant higher level of CSR commitment from their banks than do men, with the exception of those in the over-65 age group and of those in the 26-35 age group. However the most significant gender differences are encountered among the youngest clients. In addition, the analyses demonstrate that women have slightly significantly higher expectations than men for all the CSR dimensions and sub-dimensions examined.

Deepening the analysis further by "CSR issues", the study shows that gender differences are not very relevant, with only 3 out of 19 issues which present at least a small substantive significance (Cohen's $\mathrm{d} \geq 0.20$ ). Among the latter is the CSR issue of “diversity and equal opportunity”, which can be linked to the existence of a phenomenon of unequal opportunity in Italy (e.g. Peragine and Serlenga, 2008; Campus, 2010; World Economic Forum, 2013). Indeed, in keeping with the interpretation of Prasad et al. (1998), less agreement between genders indicates a society with more discrimination between genders. Concerning customer perceptions of company CSR commitment, the overall results do not show significant influence due to gender differences. When the analysis is deepened to gender differences by different education levels, different age groups and different CSR dimensions and issues, it is still not possible to say that female customers perceive CSR commitment differently than males.

These results concerning the influence of gender differences on CSR expectations coincide with the study on gender differences in business ethics by Luthar et al. (1997), thus further confirming that female clients have average expectations regarding CSR that are small but substantively significant higher than those of males. They also agree with the more specific study by Nath et al. (2013), based upon a survey of 750 US-based retail investors, 
which found that female retail investors are more demanding of CSR information when compared to male retail investors. Gender differences render women on average slightly more attentive than men concerning CSR related themes, and are particularly accentuated concerning the environmental dimension. This observation is in line with feminist environmentalism and eco-feminist theories (e.g. Agarwal, 1992; Mellor, 2006; Veuthey and Gerber, 2010), under which women would be more attentive to balancing economic goals and the needs for environmental conservation (Veuthey and Gerber, 2010). In particular, studies on pro-environmental behaviour show that women have consistently higher levels of environmental concern than men (Davidson and Freudenburg, 1996; Zelezny et al., 2000). Women are also more likely to promote pro-environmental activities in both advanced and emerging countries (Vicente-Molina et al., 2013) and are more prone than men to engage in green consumer behaviour (Straughan and Roberts, 1999; Rex and Baumann, 2007).

The present results also coincide with those of other studies regarding the non-significance of gender influences on perceptions of responsible corporate conduct (e.g. Kidwell et al., 1987; Luthar et al. 1997; Tsalikis et al., 2002).

\section{Conclusions}

Companies and government should analyse gender (but also age, education, etc.) differences in terms of CSR expectations and perceptions in order to focus their investments and policies in sustainability and strategically differentiate their efforts. The current study is thus useful for increasing the effectiveness of company strategies and government policies in designing, planning, implementing, and assessing sustainability initiatives, in terms of stakeholder satisfaction of their expectations.

The extensive literature review presented in the first part of the paper analyses the theme of gender differences in perceptions and expectations of ethics, business ethics, CSR and 
sustainability, underlining the necessity to consider substantial significance in order to avoid systematic and dangerous biases in scientific research. The substantial sample size examined and the use of a standardized measure of effect size are further aspects that render the conclusions noteworthy in deepening and updating knowledge on the themes examined. Moreover, the results are particularly interesting because recent financial scandals in the banking sector have led customers to pay increasing attention to the importance of CSR.

The authors believe that in future research, more attention needs to be paid to the influence of this and other types of diversities (e.g. cultural, ethnic, country of origin, income) on CSR expectations and perceptions, considering the intersections of the various diversity factors. It would also be of interest to analyse whether gender differences change over time and space. Such an investigation would imply whether, over time, results could be transferred from one regional setting to another. It could also be of interest to inquire into the difference in CSR perception and expectation among different kinds of stakeholders (e.g. employees, management, suppliers). Investigations such as these and the one offered here can provide useful information to decision makers for the formulation of sustainability policies and strategies, in both the public and private spheres. 


\section{References}

Agarwal, B. (1992). The gender and environment debate: lessons from India. Feminist studies, 18(1), 119-158.

Alan Willis, C. A. (2003). The role of the global reporting initiative's sustainability reporting guidelines in the social screening of investments. Journal of Business Ethics, 43(3), 233237.

Alonso-Almeida, M. d. M. (2013). Environmental management in tourism: students' perceptions and managerial practice in restaurants from a gender perspective. Journal of Cleaner Production, 60, 201-207.

Alonso-Almeida, M. d. M., Fernández de Navarrete, F. C., \& Rodriguez-Pomeda, J. (2015a). Corporate social responsibility perception in business students as future managers: a multifactorial analysis. Business Ethics: A European Review, 24(1), 1-17.

Alonso-Almeida, M. d. M., Perramon, J., \& Bagur, L. (2015b). Women managers and corporate social responsibility (CSR) in Spain: Perceptions and drivers. Women's Studies International Forum, 50, 47-56.

Aouina Mejri, C., \& Bhatli, D. (2013). CSR: Consumer responses to the social quality of private labels. Journal of Retailing and Consumer Services, DOI: 10.1016/j.jretconser.2013.08.001.

Arlow, P. (1991). Personal characteristics in college students' evaluations of business ethics and corporate social responsibility. Journal of Business Ethics, 10(1), 63-69.

Atakan, M. S., Burnaz, S., \& Topcu, Y. I. (2008). An empirical investigation of the ethical perceptions of future managers with a special emphasis on gender - Turkish case. Journal of Business Ethics, 82(3), 573-586.

Betz, M., O'Connell, L., \& Shepard, J. M. (1989). Gender differences in proclivity for 
unethical behavior. Journal of Business Ethics, 8(5), 321-324.

Borkowski, S. C., \& Ugras, Y. J. (1992). The ethical attitudes of students as a function of age, sex and experience. Journal of Business Ethics, 11(12), 961-979.

Bouten, L., Everaert, P., Van Liedekerke, L., De Moor, L., \& Christiaens, J. (2011). Corporate social responsibility reporting: a comprehensive picture?. Accounting Forum, 35(3), 187204.

Brunk, K. H., \& Blümelhuber, C. (2011). One strike and you're out: Qualitative insights into the formation of consumers' ethical company or brand perceptions. Journal of Business Research, 64(2), 134-141.

Burton, B. K., \& Hegarty, W. H. (1999). Some determinants of student corporate social responsibility orientation. Business \& society, 38(2), 188-205.

Calabrese, A., Costa, R., Menichini, T., \& Rosati, F. (2013). Does corporate social responsibility hit the mark? A stakeholder oriented methodology for CSR assessment. Knowledge and Process Management, 20(2), 77-89.

Campus, D. (2010). Political discussion, views of political expertise and women's representation in Italy. European Journal of Women's Studies, 17(3), 249-267.

Checchi, D., \& Peragine, V. (2010). Inequality of opportunity in Italy. The Journal of Economic Inequality, 8(4), 429-450.

Christensen, L. J., Peirce, E., Hartman, L. P., Hoffman, W. M., \& Carrier, J. (2007). Ethics, CSR, and sustainability education in the Financial Times top 50 global business schools: Baseline data and future research directions. Journal of Business Ethics, 73(4), 347-368.

Ciliberti, F., Pontrandolfo, P., \& Scozzi, B. (2008). Investigating corporate social responsibility in supply chains: a SME perspective. Journal of Cleaner Production, 16(15), $1579-1588$.

Coe, R. (2002). It's the effect size, stupid: What effect size is and why it is important. Annual 
Conference of the British Educational Research Association. University of Exeter. England.

Cohen, J. (1988). Statistical Power Analysis for the Behavioral Sciences, 2nd edition. Lawrence Erlbaum, Hillsdale, NJ.

Collins, D. (2000). The quest to improve the human condition: the first 1,500 articles published in Journal of Business Ethics. Journal of Business Ethics, 26(1), 1-73.

Cosma, S., \& Gualandri, E. (2012). The Italian Banking System: Impact of the Crisis and Future Perspectives. Palgrave Macmillan, London, UK.

Crandall, C. S., Tsang, J. A., Goldman, S., \& Pennington, J. T. (1999). Newsworthy moral dilemmas: justice, caring, and gender. Sex Roles, 40(3-4), 187-209.

Crooks, E. (2012). BP: The case of the century. Financial Times Magazine. 24 February.

D’Aquila, J. D., Bean, D. F., \& Procario-Foley, E. G. (2004). Students' perception of the ethical business climate: a comparison with leaders in the community. Journal of Business Ethics, 51(2), 155-166.

Davidson, D., Freudenburg, W. (1996). Gender and environmental risk concerns: a review and analysis of available research. Environmental Behaviour, 28, 302-339.

Dawson, L. M. (1997). Ethical differences between men and women in the sales profession. Journal of Business Ethics, 16(11), 1143-1152.

Dellaportas, S. (2006). Making a difference with a discrete course on accounting ethics. Journal of Business Ethics, 65(4), 391-404.

Derry, R. (1989). An empirical study of moral reasoning among managers. Journal of Business Ethics, 8(11), 855-862.

Deshpande, S. P., Joseph, J., \& Maximov, V. V. (2000). Perceptions of proper ethical conduct of male and female Russian managers. Journal of Business Ethics, 24(2), 179-183.

Ekin, M. S. A., \& Tezölmez, S. H. (1999). Business ethics in Turkey: an empirical 
investigation with special emphasis on gender. Journal of Business Ethics, 18(1), 17-34.

Elias, R. (2004). An examination of business students' perception of corporate social responsibilities before and after bankruptcies. Journal of Business Ethics, 52, 267-281.

Ellis, P. D. (2010). Effect sizes and the interpretation of research results in international business. Journal of International Business Studies, 41(9), 1581-1588.

Ergeneli, A., \& Arıkan, S. (2002). Gender differences in ethical perceptions of salespeople: An empirical examination in Turkey. Journal of Business Ethics, 40(3), 247-260.

European Commission. (2011). A renewed EU strategy 2011-14 for corporate social responsibility. Brussels: European Commission.

Eweje, G., \& Brunton, M. (2010). Ethical perceptions of business students in a New Zealand university: Do gender, age and work experience matter? Business Ethics: A European Review, 19(1), 95-111.

Fassin, Y., \& Gosselin, D. (2011). The collapse of a European bank in the financial crisis: an analysis from stakeholder and ethical perspectives. Journal of business ethics, 102(2), 169191.

Fernandez-Feijoo, B., Romero, S., \& Ruiz, S. (2014). Commitment to Corporate social responsibility measured through global reporting initiative reporting: factors affecting the behavior of companies. Journal of Cleaner Production, 81, 244-254.

Filippin, A., \& Crosetto, P. (2014). A reconsideration of gender differences in risk attitudes. IZA Discussion Paper No. 8184. Available at SSRN: http://ssrn.com/abstract=2441480

Fine, C. (2010). Delusions of gender: How our minds, society, and neurosexism create difference. New York, WW Norton \& Company.

Ford, R. C., \& Richardson, W. D. (1994). Ethical decision making: a review of the empirical literature. Journal of Business Ethics, 13(3), 205-221.

Fritzsche, D. J. (1988). An examination of marketing ethics: role of the decision maker, 
consequences of the decision, management position, and sex of the respondent. Journal of Macromarketing, 8(2), 29-39.

Gholipour, T. H., Nayeri, M. D., \& Mir-Mehdi, S. M. (2012). Investigation of attitudes about corporate social responsibility: business students in Iran. African Journal of Business Management, 6(14), 5105-5113.

Gilligan, C. (1982). In a Different voice: Psychological Theory and Women's Development. Harvard University Press, Cambridge, MA.

Global Reporting Initiative. (2011). G3.1, Sustainability reporting guidelines. From www.globalreporting.org (last consulted 18/06/2015).

Gordon, I. M. (1998). Enhancing students' knowledge of social responsibility accounting. Issues in Accounting Education, 13, 31-46.

Grosser, K. (2009). Corporate social responsibility and gender equality: women as stakeholders and the European Union sustainability strategy. Business Ethics: A European Review, 18(3), 290-307.

Grosser, K., \& Moon, J. (2005). Gender mainstreaming and corporate social responsibility: Reporting workplace issues. Journal of Business Ethics, 62(4), 327-340.

Grosser, K., \& Moon, J. (2008). Developments in company reporting on workplace gender equality?: A corporate social responsibility perspective. Accounting Forum, 32(3), 179198.

Guthrie, J., \& Abeysekera, I. (2006). Content analysis of social, environmental reporting: what is new?. Journal of Human Resource Costing \& Accounting, 10(2), 114-126.

Hay, D., McCourt Larres, P., Oyelere, P., \& Fisher, A. (2001). The ethical perception of undergraduate students in computer-related situations: an analysis of the effects of culture, gender and prior education. Teaching Business Ethics, 5(3), 331-356.

Hyde, J. S. (2005). The gender similarities hypothesis. American psychologist, 60(6), 581- 
592.

Jordan-Young, R. M. (2010). Brain Storm: The Flaws in the Science of Sex Differences. Cambridge, Harvard University Press.

Keith, N. K., Perreault, H. R., Chin, M., \& Keith, M. (2009). The effect of gender on the importance of business ethics and managerial decisions: a student perspective. Delta Pi Epsilon Journal, 51(3), 125-136.

Kelley, K., \& Preacher, K. J. (2012). On effect size. Psychological Methods, 17(2), 137-152.

Kelley, S. W., Ferrell, O. C., \& Skinner, S. J. (1990). Ethical behavior among marketing researchers: An assessment of selected demographic characteristics. Journal of business Ethics, 9(8), 681-688.

Kidwell, J. M., Stevens, R. E., \& Bethke, A. L. (1987). Differences in ethical perceptions between male and female managers: myth or reality? Journal of Business Ethics, 6(6), 489493.

Krippendorff, K. (2004). Content Analysis, an Introduction to its Methodology. Sage Publications Inc., Thousand Oaks, CA.

Lämsä, A. M., Vehkaperä, M., Puttonen, T., \& Pesonen, H. L. (2008). Effect of business education on women and men students' attitudes on corporate responsibility in society. Journal of Business Ethics, 82(1), 45-58.

Larson, A., \& Freeman, R. E. (1997). Womecn's studies and business ethics: Towards a new conversation. Oxford University Press, New York.

Lombard, M., Snyder-Duch, J., \& Bracken, C. C. (2002). Content analysis in mass communication: assessment and reporting of intercoder reliability. Human Communication Research, 28(4), 587-604.

Lozano, R. (2006). Incorporation and institutionalisation of SD into universities: breaking through barriers to change. Journal of Cleaner Production. 14 (9-11), 787-796. 
Lozano, R., Lukman, R., Lozano, F.J., Huisingh, D., \& Lambrechts, W. (2013). Declarations for sustainability in higher education: becoming better leaders, through addressing the university system. Journal of Cleaner Production, 48, 10-19.

Luchs, M. G., \& Mooradian, T. A. (2012). Sex, personality, and sustainable consumer behaviour: Elucidating the gender effect. Journal of Consumer Policy, 35(1), 127-144.

Luthar, H. K., DiBattista, R. A., \& Gautschi, T. (1997). Perception of what the ethical climate is and what it should be: the role of gender, academic status, and ethical education. Journal of Business Ethics, 16(2), 205-217.

Meyers-Levy, J., \& Loken, B. (2015). Revisiting gender differences: What we know and what lies ahead. Journal of Consumer Psychology, 25(1), 129-149.

Manring, S. L. (2014). The role of universities in developing interdisciplinary action research collaborations to understand and manage resilient social-ecological systems. Journal of Cleaner Production, 64, 125-135.

Marimon, F., Alonso-Almeida, M. d. M., Rodríguez, M. P., \& Cortez, A. K. A. (2012). The worldwide diffusion of the global reporting initiative: what is the point?. Journal of Cleaner Production, 33, 132-144.

Marz, J. W., Powers, T. L., \& Queisser, T. (2003). Corporate and individual influences on managers' social orientation. Journal of Business Ethics, 46(1), 1-11.

Mason, E. S., \& Mudrack, P. E. (1996). Gender and ethical orientation: a test of gender and occupational socialization theories. Journal of Business Ethics, 15(6), 599-604.

McCabe, A. C., Ingram, R., \& Dato-on, M. C. (2006). The business of ethics and gender. Journal of Business Ethics, 64(2), 101-116.

McDaniel, C., Shoeps, N., \& Lincourt, J. (2001). Organizational ethics: perceptions of employees by gender. Journal of Business Ethics, 33(3), 245-256.

McNichols, C. W., \& Zimmerer, T. W. (1985). Situational ethics: an empirical study of 
differentiators of student attitudes. Journal of Business Ethics, 4(3), 175-180.

Mellor, M. (2006). Ecofeminist political economy. International Journal of Green Economics, 1(1), 139-150.

Nath, L., Holder-Webb, L., \& Cohen, J. (2013). Will women lead the way? Differences in demand for corporate social responsibility information for investment decisions. Journal of Business Ethics, 118(1), 85-102.

Nelson, J. A. (2013a). The power of stereotyping and confirmation bias to overwhelm accurate assessment: the case of economics, gender, and risk aversion. Journal of Economic Methodology. Forthcoming. The Selected Works of Julie A. Nelson. Available at: http://works.bepress.com/julie_nelson1/29

Nelson, J. A. (2013b). Not-So-Strong Evidence for Gender Differences in Risk Taking. The Selected Works of Julie A. Nelson. Available at: http://works.bepress.com/julie_nelson1/28

Nelson, J. A. (2014). Are Women Really More Risk-Averse than Men? A Re-Analysis of the Literature Using Expanded Methods. Journal of Economic Surveys. DOI: 10.1111/joes.12069

Neuendorf, K. (2002). The Content Analysis Guidebook. Sage Publications, Thousand Oaks, CA.

Ng, E. S., \& Burke, R. J. (2010). Predictor of business students’ attitudes toward sustainable business practices. Journal of Business Ethics, 95(4), 603-615.

O'Hara, S. (2009). Feminist ecological economics: theory and practice. In Eco-Sufficiency and Global Justice. Pluto Press, New York, NY, 152-175.

Panwar, R., Hansen, E., \& Anderson, R. (2010). Students' perceptions regarding CSR success of the US forest products industry. Social Responsibility Journal, 6(1), 18-32.

Peragine, V., \& Serlenga, L. (2008). Higher education and equality of opportunity in Italy. In 
J. Bishop and B. Zheng (eds), Research in Economic Inequality, 16, 67-97. Emerald Group, Bingley, UK.

Pérez, A., \& Rodríguez del Bosque, I. (2013). Customer personal features as determinants of the formation process of corporate social responsibility perceptions. Psychology \& Marketing, 30(10), 903-917.

Perkins, P. E. (2007). Feminist ecological economics and sustainability. Journal of Bioeconomics, 9(3), 227-244.

Peterson, D., Rhoads, A., \& Vaught, B. C. (2001). Ethical beliefs of business professionals: A study of gender, age and external factors. Journal of Business Ethics, 31(3), 225-232.

Piper, L., Mang, C., Knox, J., \& Waddell, C. (2012). Student perceptions toward a triple bottom line approach. Journal of Academic and Business Ethics, 6, 1-18.

Pomarici, E., \& Vecchio, R. (2014). Millennial generation attitudes to sustainable wine: an exploratory study on Italian consumers. Journal of Cleaner Production, 66, 537-545.

Prasad, J. N., Marlow, N., \& Hattwick, R. E. (1998). Gender-based differences in perception of a just society. Journal of Business Ethics, 17(3), 219-228.

Rex, E., \& Baumann, H. (2007). Beyond ecolabels: what green marketing can learn from conventional marketing. Journal of Cleaner Production, 15 (6), 567-576.

Robin, D., \& Babin, L. (1997). Making sense of the research on gender and ethics in business: a critical analysis and extension. Business Ethics Quarterly, 7(4), 61-90.

Roxas, M. L., \& Stoneback, J. Y. (2004). The importance of gender across cultures in ethical decision-making. Journal of Business Ethics, 50(2), 149-165.

Ruegger, D., \& King, E. W. (1992). A study of the effect of age and gender upon student business ethics. Journal of Business Ethics, 11(3), 179-186.

Sankaran, S., \& Bui, T. (2003). Relationship between Student Characteristics and Ethics: Implications for Educators. Journal of Instructional Psychology, 30(3), 240-253. 
Seyfang, G. (2009). The new economics of sustainable consumption: seeds of change. Palgrave Macmillan, Basingstoke, UK.

Shauki, E. (2011). Perceptions on corporate social responsibility: A study in capturing public confidence. Corporate Social Responsibility and Environmental Management, 18(3), 200208.

Simga-Mugan, C., Daly, B. A., Onkal, D., \& Kavut, L. (2005). The influence of nationality and gender on ethical sensitivity: an application of the issue-contingent model. Journal of Business Ethics, 57(2), 139-159.

Sims, R. R., \& Brinkmann, J. (2003). Enron Ethics (Or: Culture Matters More than Codes). Journal of Business Ethics, 45, 243-256.

Smith, P. L., \& Oakley, E. F, III. (1997). Gender-related differences in ethical and social values of business students: implications for management. Journal of Business Ethics, 16(1), 37-45.

Smith, S., \& Kumar, A. (2013). Impact of corporate social responsibility on employee organizational commitment within the gaming industry. Advances in Hospitality and Leisure, 9, 49-67.

Sobczak, A., Debucquet, G., \& Havard, C. (2006). The impact of higher education on students’ and young managers’ perception of companies and CSR: an exploratory analysis. Corporate Governance, 6, 463-474.

Social Accountability Accreditation Services (2015). SA8000 Certified Organisations, Pie Chart, By Country. Available at: http://www.saasaccreditation.org/SA8000_Certified_Organisations_Pie_Chart_by_Countr $\mathrm{y}$

Straughan, R. D., \& Roberts, J. A. (1999). Environmental segmentation alternatives: a look at green consumer behavior in the new millennium. Journal of Consumer Marketing, 16(6), 
558-575.

Striukova, L., Unerman, J., \& Guthrie, J. (2008). Corporate reporting of intellectual capital: evidence from UK companies. The British Accounting Review, 40(4), 297-313.

Sullivan, G. M., \& Feinn, R. (2012). Using effect size-or why the P value is not enough. Journal of graduate medical education, 4(3), 279-282.

Tsalikis, J., Seaton, B., \& Tomaras, P. (2002). A new perspective on cross-cultural ethical evaluations: the use of conjoint analysis. Journal of Business Ethics, 35(4), 281-292.

Veuthey, S., \& Gerber, J. F. (2010). Logging conflicts in Southern Cameroon: a feminist ecological economics perspective. Ecological economics, 70(2), 170-177.

Vicente-Molina, M. A., Fernández-Sáinz, A., \& Izagirre-Olaizola, J. (2013). Environmental knowledge and other variables affecting pro-environmental behaviour: comparison of university students from emerging and advanced countries. Journal of Cleaner Production, $61,130-138$

Waas, T., Verbruggen, A., \& Wright, T. (2010). University research for sustainable development: definition and characteristics explored. Journal of Cleaner Production, 18 (7), 629-636.

Wang, P., Liu, Q., \& Qi, Y. (2014). Factors influencing sustainable consumption behaviors: a survey of the rural residents in China. Journal of Cleaner Production, 63, 152-165.

Wigley, S. (2008). Gauging consumers' responses to CSR activities: Does increased awareness make cents? Public Relations Review, 34(3), 306-308.

World Commission on Environment and Development. (1987) Our common future. Available at http://www.un-documents.net/our-common-future.pdf (last consulted 18/06/2015).

World Economic Forum (2013). The Global Gender Gap Report 2013. Available at http://www.weforum.org/reports/global-gender-gap-report-2013 (last consulted 18/06/2015). 
Yankelovich, D. (1972). The changing values on campus: Political and personal attitudes of today's college students. Simon and Schuster, New York.

Zhao, H. H., Gao, Q., Wu, Y. P., Wang, Y., \& Zhu, X. D. (2014). What affects green consumer behavior in China? A case study from Qingdao. Journal of Cleaner Production, 63, 143-151.

Zelezny, L. C., Chua, P. P., \& Aldrich, C. (2000). New ways of thinking about environmentalism: Elaborating on gender differences in environmentalism. Journal of Social Issues, 56(3), 443-457.

Ziliak, S. T., \& McCloskey, D. N. (2008). The cult of statistical significance: How the standard error costs us jobs, justice, and lives. University of Michigan Press. 
Tables

\begin{tabular}{|c|c|c|c|c|c|c|}
\hline $\begin{array}{l}\text { Research } \\
\text { topic }\end{array}$ & Author & Year & Perceptions & Expectations & Attitudes & Stakeholder under analysis \\
\hline $\begin{array}{c}\text { Ethics \& } \\
\text { values }\end{array}$ & $\begin{array}{l}\text { Yankelovich } \\
\text { Gilligan } \\
\text { Crandall et al. }\end{array}$ & $\begin{array}{l}1972 \\
1982 \\
1999\end{array}$ & & & $\begin{array}{l}\sqrt{ } \\
\sqrt{ } \\
\sqrt{ }\end{array}$ & $\begin{array}{l}\text { Students } \\
\text { Society } \\
\text { Students }\end{array}$ \\
\hline $\begin{array}{l}\text { Business } \\
\text { Ethics }\end{array}$ & $\begin{array}{l}\text { McNichols and Zimmerer } \\
\text { Kidwell et al. } \\
\text { Fritzsche } \\
\text { Prasad et al. } \\
\text { Betz et al. } \\
\text { Derry } \\
\text { Kelley et al. } \\
\text { Arlow } \\
\text { Borkowski and Ugras } \\
\text { Ruegger and King } \\
\text { Mason and Mudrack } \\
\text { Smith and Oakley } \\
\text { Robin and Babin } \\
\text { Luthar et al. } \\
\text { Dawson } \\
\text { Ekin and Tezolmez } \\
\text { Deshpande et al. } \\
\text { Hay et al. } \\
\text { McDaniel et al. } \\
\text { Peterson et al. } \\
\text { Ergeneli and Arikan } \\
\text { Tsalikis et al. } \\
\text { Sankaran and Bui } \\
\text { D'Aquila et al. } \\
\text { Roxas and Stoneback } \\
\text { Sigma-Mugan et al. } \\
\text { McCabe et al. } \\
\text { Atakan et al. } \\
\text { Keith et al. } \\
\text { Eweje and Brunton }\end{array}$ & $\begin{array}{l}1985 \\
1987 \\
1988 \\
1998 \\
1989 \\
1989 \\
1990 \\
1991 \\
1992 \\
1992 \\
1996 \\
1997 \\
1997 \\
1997 \\
1997 \\
1999 \\
2000 \\
2001 \\
2001 \\
2001 \\
2002 \\
2002 \\
2003 \\
2004 \\
2004 \\
2005 \\
2006 \\
2008 \\
2009 \\
2010 \\
\end{array}$ & $\begin{array}{l}\sqrt{ } \\
\sqrt{ } \\
\sqrt{ } \\
\sqrt{ } \\
\sqrt{ } \\
\sqrt{ } \\
\\
\sqrt{ } \\
\sqrt{ } \\
\sqrt{ } \\
\sqrt{ } \\
\sqrt{ } \\
\sqrt{ } \\
\sqrt{ }\end{array}$ & $\sqrt{ }$ & $\begin{array}{l}\sqrt{ } \\
\sqrt{ } \\
\sqrt{ } \\
\sqrt{ } \\
\sqrt{ } \\
\sqrt{ } \\
\sqrt{ } \\
\sqrt{ } \\
\sqrt{ } \\
\sqrt{ } \\
\sqrt{ } \\
\sqrt{ } \\
\sqrt{ } \\
\sqrt{ } \\
\sqrt{ }\end{array}$ & $\begin{array}{l}\text { Students } \\
\text { Employees } \\
\text { Employees } \\
\text { Students } \\
\text { Students } \\
\text { Employees } \\
\text { Customers } \\
\text { Students } \\
\text { Students } \\
\text { Students } \\
\text { Students } \\
\text { Students } \\
\text { Students and Employees } \\
\text { Students } \\
\text { Employees } \\
\text { Employees } \\
\text { Employees } \\
\text { Students } \\
\text { Employees } \\
\text { Employees } \\
\text { Employees } \\
\text { Students } \\
\text { Students } \\
\text { Students } \\
\text { Students } \\
\text { Employees } \\
\text { Students } \\
\text { Students } \\
\text { Students } \\
\text { Students }\end{array}$ \\
\hline CSR & $\begin{array}{l}\text { Arlow } \\
\text { Burton and Hegarty } \\
\text { Marz et al. } \\
\text { Elias } \\
\text { Lämsä et al. } \\
\text { Panwar et al. } \\
\text { Shauki } \\
\text { Gholipour et al. } \\
\text { Smith and Kumar } \\
\text { Perez and Rodríguez del Bosque } \\
\text { Alonso-Almeida } \\
\text { Aouina Mejri and Bhatli } \\
\text { Alonso-Almeida et al. }\end{array}$ & $\begin{array}{l}1991 \\
1999 \\
2003 \\
2004 \\
2008 \\
2010 \\
2011 \\
2012 \\
2013 \\
2013 \\
2013 \\
2013 \\
2015 a\end{array}$ & $\begin{array}{l}\sqrt{ } \\
\sqrt{ } \\
\sqrt{ } \\
\sqrt{ } \\
\sqrt{ } \\
\sqrt{ }\end{array}$ & $\begin{array}{l}\sqrt{ } \\
\sqrt{ } \\
\sqrt{ }\end{array}$ & $\begin{array}{l}\sqrt{ } \\
\sqrt{ } \\
\sqrt{ } \\
\sqrt{ }\end{array}$ & $\begin{array}{l}\text { Students } \\
\text { Students } \\
\text { Employees } \\
\text { Students } \\
\text { Students } \\
\text { Students } \\
\text { Stakeholders } \\
\text { Students } \\
\text { Employees } \\
\text { Customers } \\
\text { Students and Employees } \\
\text { Customers } \\
\text { Students }\end{array}$ \\
\hline Sustainability & $\begin{array}{l}\text { Ng and Burke } \\
\text { Luchs and Mooradian } \\
\text { Pomarici and Vecchio } \\
\text { Vicente-Molina et al. } \\
\text { Zhao et al. } \\
\text { Wang et al. }\end{array}$ & $\begin{array}{l}2010 \\
2010 \\
2014 \\
2013 \\
2014 \\
2014\end{array}$ & & & $\begin{array}{l}\sqrt{ } \\
\sqrt{ } \\
\sqrt{ } \\
\sqrt{ } \\
\sqrt{ } \\
\sqrt{ }\end{array}$ & $\begin{array}{l}\text { Students } \\
\text { Students } \\
\text { Customers } \\
\text { Students } \\
\text { Customers } \\
\text { Customers }\end{array}$ \\
\hline
\end{tabular}

Table 1: Studies on gender differences in ethics, business ethics, CSR and sustainability. 


\begin{tabular}{|c|c|c|c|c|c|}
\hline Author(s) & Year & Cohen's d & Type of Study & Variable & $\mathrm{N}$ \\
\hline $\begin{array}{l}\text { Mason and } \\
\text { Mudrack }\end{array}$ & 1996 & .33 & $\begin{array}{l}\text { Gender and ethical orientation: a } \\
\text { test of gender and occupational } \\
\text { socialization theories }\end{array}$ & Attitudes & 308 \\
\hline Smith and Oakley & 1997 & $\begin{array}{l}\text { NSS (rule-based issues) to } \\
.56 \text { (social concerns) }\end{array}$ & $\begin{array}{l}\text { Gender-related differences in } \\
\text { ethical and social values of } \\
\text { business students }\end{array}$ & Attitudes & 318 \\
\hline Dawson & 1997 & $\begin{array}{c}-.46 \text { to NSS to } .62(\text { mean }= \\
.29)^{*}\end{array}$ & $\begin{array}{l}\text { Ethical gender differences in the } \\
\text { sales profession }\end{array}$ & Attitudes & 203 \\
\hline Luthar et al. & 1997 & NSS (How it is) & $\begin{array}{c}\text { Perception of what the climate is } \\
\text { and what it should be: the role of } \\
\text { gender }\end{array}$ & Perceptions & 658 \\
\hline Luthar et al. & 1997 & .39 (How it should be) & $\begin{array}{l}\text { Perception of what the climate is } \\
\text { and what it should be: the role of } \\
\text { gender }\end{array}$ & Expectations & 658 \\
\hline Prasad et al. & 1998 & $\begin{array}{c}-.43 \text { to NSS to } .41(\text { mean }= \\
-.20)^{*}\end{array}$ & $\begin{array}{l}\text { Gender-based differences in } \\
\text { perception of a just society }\end{array}$ & Perceptions & 191 \\
\hline Prasad et al. & 1998 & NSS to .44 (mean $=.40)^{*}$ & $\begin{array}{l}\text { Gender-based differences in } \\
\text { perception of a just society }\end{array}$ & Expectations & 191 \\
\hline Burton and Hegarty & 1999 & $\begin{array}{c}-.72 \text { to NSS to } .66(\text { mean }= \\
.17)^{*}\end{array}$ & Student CSR Orientation & Attitudes & 219 \\
\hline Deshpande et al. & 2000 & NSS to $.28(\text { mean }=.25)^{*}$ & $\begin{array}{l}\text { Ethical conduct of male and } \\
\text { female Russian managers }\end{array}$ & Attitudes & 129 \\
\hline McDaniel et al. & 2001 & $\begin{array}{c}-.52 \text { to NSS to } 0.41 \text { (mean } \\
=-.18)^{*}\end{array}$ & $\begin{array}{l}\text { Organizational ethics: } \\
\text { perceptions of employees by } \\
\text { gender }\end{array}$ & Perceptions & 1,712 \\
\hline Ergeneli and Arikan & 2002 & $\begin{array}{c}-.31 \text { to NSS to } .41(\text { mean }= \\
.21)^{*}\end{array}$ & $\begin{array}{c}\text { Gender differences in } \\
\text { salespeople's ethical scenarios }\end{array}$ & Attitudes & 248 \\
\hline Sankaran and Bui & 2003 & NSS & $\begin{array}{l}\text { Relationship between student } \\
\text { characteristics and ethics }\end{array}$ & Attitudes & 345 \\
\hline D'Aquila et al. & 2004 & $\begin{array}{c}-.27 \text { to NSS to } .24(\text { mean }= \\
-.14)^{*}\end{array}$ & $\begin{array}{l}\text { Students perception of the ethical } \\
\text { business climate }\end{array}$ & Perceptions & 476 \\
\hline Sigma-Mugan et al. & 2005 & NSS to $.65(\text { mean }=.46)^{* *}$ & $\begin{array}{c}\text { The influence of gender on } \\
\text { ethical sensitivity }\end{array}$ & Attitudes & 120 \\
\hline McCabe et al. & 2006 & -.63 to NSS (mean = -.20) & The business of ethics and gender & Perceptions & 221 \\
\hline Lämsä et al. & 2008 & .27 to $.72(\text { mean }=.46)^{*}$ & $\begin{array}{l}\text { women and men students' } \\
\text { attitudes on CSR }\end{array}$ & Attitudes & 217 \\
\hline Gholipou & 2012 & NSS & $\begin{array}{l}\text { Investigation of CSR attitudes of } \\
\text { business students in Iran }\end{array}$ & Attitudes & 320 \\
\hline $\begin{array}{l}\text { Perez and } \\
\text { Rodríguez del } \\
\text { Bosque }\end{array}$ & 2013 & NSS & $\begin{array}{l}\text { Customer personal features as } \\
\text { determinants of the formation } \\
\text { process of CSR perceptions }\end{array}$ & Perceptions & 1,124 \\
\hline $\begin{array}{l}\text { Alonso-Almeida et } \\
\text { al. }\end{array}$ & $2015 a$ & .20 to $.29($ mean $=.24) *$ & $\begin{array}{l}\text { CSR attitudes and perceptions in } \\
\text { business students }\end{array}$ & Attitudes & 535 \\
\hline
\end{tabular}

\section{Table 2: Magnitudes of Male vs. Female differences in business ethics and CSR literature.}

* means calculated only on those items for which gender differences are statistically significant.

**only for 4 items out of 16 (i.e. items for which gender differences are statistically significant) data is available. 


\begin{tabular}{|c|c|c|c|c|}
\hline CSR dimensions & CSR sub-dimensions & CSR issues & Corresponding GRI indicators & Brief description \\
\hline \multirow{3}{*}{ Economic (EC) } & \multirow{3}{*}{ - } & Direct economic value & EC1 & $\begin{array}{l}\text { Direct economic value generated and distributed, e.g. employee } \\
\text { compensation, donations and other community investments. }\end{array}$ \\
\hline & & Market presence & EC5, EC6, EC7 & $\begin{array}{l}\text { The organization's contribution to the sustainability of the local } \\
\text { economic system, e.g. spending on locally-based suppliers. }\end{array}$ \\
\hline & & Indirect Economic Impacts & EC8, EC9 & $\begin{array}{l}\text { Indirect economic impacts on the local economic system, e.g. } \\
\text { investments in public infrastructure and services. }\end{array}$ \\
\hline \multirow{3}{*}{ Environmental (EN) } & \multirow{3}{*}{ - } & Materials & EN1, EN2 & $\begin{array}{l}\text { Efforts to reduce the material intensity and the ability to use } \\
\text { recycled input materials. }\end{array}$ \\
\hline & & Waste & EN22, EN24 & $\begin{array}{l}\text { Waste reduction efforts and the contribution to improper transport } \\
\text { of dangerous wastes elimination. }\end{array}$ \\
\hline & & Compliance & EN28 & Compliance with environmental laws and regulations. \\
\hline \multirow{13}{*}{ Social } & \multirow{4}{*}{$\begin{array}{l}\text { Labor Practices and } \\
\text { Decent Work (LA) }\end{array}$} & Employment & LA1, LA2, LA3, LA15 & Job stability and equity by gender, age, group and region. \\
\hline & & Labor/Management Relations & LA4, LA5 & Consultation with workers and other relevant parties. \\
\hline & & Training and Education & LA10, LA11, LA12 & Training and assistance programs to upgrade employee skills. \\
\hline & & Diversity and Equal Opportunity & LA13, LA14 & $\begin{array}{l}\text { Equal opportunity in salary and in the composition of workforce } \\
\text { and governance bodies (according to gender, age, race, etc.). }\end{array}$ \\
\hline & \multirow{2}{*}{ Human Rights (HR) } & Non-discrimination & HR4 & $\begin{array}{l}\text { Non-discrimination on grounds of race, gender, religion, political } \\
\text { opinion, nationality, or social origin. }\end{array}$ \\
\hline & & $\begin{array}{l}\text { Indigenous Rights and local } \\
\text { communities }\end{array}$ & HR9 & Respect of the indigenous and local communities rights. \\
\hline & \multirow{4}{*}{ Society (SO) } & Corruption & $\mathrm{SO} 2, \mathrm{SO} 3, \mathrm{SO} 4$ & $\begin{array}{l}\text { Existence of supporting procedures and employee training to } \\
\text { manage reputational risks arising from corruption. }\end{array}$ \\
\hline & & Public Policy & SO5, SO6 & $\begin{array}{l}\text { Extent to which publicly-expressed positions on sustainability are } \\
\text { consistently embedded across the organization. }\end{array}$ \\
\hline & & Anti-Competitive Behavior & SO7 & $\begin{array}{l}\text { Actions that may result in collusion with potential competitors } \\
\text { with the purpose of limiting the effects of market competition. }\end{array}$ \\
\hline & & Compliance & SO8 & $\begin{array}{l}\text { Compliance with laws and regulations related to accounting fraud, } \\
\text { workplace discrimination and corruption. }\end{array}$ \\
\hline & \multirow{3}{*}{$\begin{array}{l}\text { Product Responsibility } \\
\text { (PR) }\end{array}$} & Marketing Communications & PR6, PR7 & $\begin{array}{l}\text { Marketing communications practices conforming to generally } \\
\text { accepted ethical standards and privacy regulations. }\end{array}$ \\
\hline & & Customer Privacy & PR8 & $\begin{array}{l}\text { Existence of management systems and procedures to ensure } \\
\text { customer privacy protection. }\end{array}$ \\
\hline & & Compliance & PR9 & $\begin{array}{l}\text { Compliance with laws and regulations concerning provision and } \\
\text { use of product and services. }\end{array}$ \\
\hline
\end{tabular}

\section{Table 3: CSR dimensions, sub-dimensions and issues considered in the study.}


This is the accepted version of the research article: Calabrese, A., Costa, R., \& Rosati, F. (2016). Gender differences in customer expectations and perceptions of corporate social responsibility. Journal of Cleaner Production, 116, 135-149. Available in final form at: http://www.sciencedirect.com/science/article/pii/S0959652615019253

\begin{tabular}{ccccc}
\hline & & \multicolumn{2}{c}{ Gender } & \multirow{2}{*}{ Total } \\
\cline { 3 - 4 } & & Female & Male & \\
\hline \multirow{4}{*}{ Education } & $54(12.5 \%)$ & $79(16.6 \%)$ & $133(14.7 \%)$ \\
& Medium & $175(40.4 \%)$ & $203(42.8 \%)$ & $378(41.6 \%)$ \\
& High & $204(47.1 \%)$ & $193(40.6 \%)$ & $397(43.7 \%)$ \\
\hline \multirow{4}{*}{ Age } & $<26$ & $79(18.2 \%)$ & $92(19.4 \%)$ & $171(18.9 \%)$ \\
& $26-35$ & $100(23.1 \%)$ & $90(19.0 \%)$ & $190(20.9 \%)$ \\
& $36-50$ & $114(26.3 \%)$ & $124(26.1 \%)$ & $238(26.2 \%)$ \\
& $51-65$ & $92(21.3 \%)$ & $117(24.6 \%)$ & $209(23.0 \%)$ \\
& $>65$ & $48(11.1 \%)$ & $52(10.9 \%)$ & $100(11.0 \%)$ \\
\hline \multicolumn{2}{c}{ Total } & $433(47.7 \%)$ & $475(52.3 \%)$ & $908(100.0 \%)$ \\
\hline
\end{tabular}

Table 4: Characteristics of the sample population of bank customers, by gender, level of education and age group.

(Low education - middle school diploma; Medium education - high school diploma, High education - bachelor's degree or further) 


\begin{tabular}{clcccccc}
\hline CSR Exp./Perc. & Gender & $N$ & Mean & Std. deviation & Std. error mean & $t$-test p & Cohen's $d$ \\
\hline \multirow{2}{*}{ Expectations } & Female & 433 & 4.13 & 0.574 & 0.028 & 0.000 & 0.24 \\
& Male & 475 & 3.99 & 0.613 & 0.028 & $* * *$ & \\
\multirow{2}{*}{ Perceptions } & Female & 433 & 3.16 & 0.742 & 0.036 & 0.139 & \multirow{2}{*}{ NSS } \\
& Male & 475 & 3.11 & 0.736 & 0.034 & & \\
\hline
\end{tabular}

Table 5: CSR expectations and perceptions compared by gender.

Statistical significance: ${ }^{*} p$-value $<0.10,{ }^{* *} p$-value $<0.05$, ${ }^{* * *} p$-value $<0.01$ 


\begin{tabular}{|c|c|c|c|c|c|c|c|c|}
\hline CSR Exp./Perc. & Education & Gender & $N$ & Mean & Std. deviation & Std. error mean & $t$-test $\mathrm{p}$ & Cohen's $d$ \\
\hline \multirow{6}{*}{ Expectations } & \multirow{2}{*}{ Low } & Female & 54 & 3.83 & 0.846 & 0.115 & 0.018 & \multirow[t]{2}{*}{0.37} \\
\hline & & Male & 79 & 3.52 & 0.847 & 0.095 & $* *$ & \\
\hline & \multirow{2}{*}{ Medium } & Female & 175 & 4.15 & 0.593 & 0.045 & 0.035 & \multirow[t]{2}{*}{0.18} \\
\hline & & Male & 203 & 4.05 & 0.553 & 0.039 & $* *$ & \\
\hline & \multirow{2}{*}{ High } & Female & 204 & 4.19 & 0.432 & 0.030 & 0.052 & \multirow[t]{2}{*}{ NSS } \\
\hline & & Male & 193 & 4.12 & 0.449 & 0.032 & * & \\
\hline \multirow{6}{*}{ Perceptions } & \multirow{2}{*}{ Low } & Female & 54 & 3.00 & 0.685 & 0.093 & \multirow[t]{2}{*}{0.141} & \multirow[t]{2}{*}{ NSS } \\
\hline & & Male & 79 & 2.87 & 0.753 & 0.085 & & \\
\hline & \multirow{2}{*}{ Medium } & Female & 175 & 3.15 & 0.728 & 0.055 & \multirow[t]{2}{*}{0.180} & \multirow[t]{2}{*}{ NSS } \\
\hline & & Male & 203 & 3.08 & 0.771 & 0.054 & & \\
\hline & \multirow{2}{*}{ High } & Female & 204 & 3.21 & 0.765 & 0.054 & \multirow[t]{2}{*}{0.367} & \multirow[t]{2}{*}{ NSS } \\
\hline & & Male & 193 & 3.23 & 0.665 & 0.048 & & \\
\hline
\end{tabular}

Table 6: CSR expectations and perceptions compared by gender and level of education.

Statistical significance: ${ }^{*} p$-value $<0.10,{ }^{* *} p$-value $<0.05,{ }^{* * *}$-value $<0.01$ 


\begin{tabular}{|c|c|c|c|c|c|c|c|c|}
\hline CSR Exp./Perc. & Age & Gender & $N$ & Mean & Std. deviation & Std. error mean & $t$-test $\mathrm{p}$ & Cohen's $d$ \\
\hline \multirow{10}{*}{ Expectations } & \multirow{2}{*}{$<=25$} & Female & 79 & 4.19 & 0.588 & 0.066 & \multirow{2}{*}{$\begin{array}{c}0.003 \\
* * *\end{array}$} & \multirow[t]{2}{*}{0.42} \\
\hline & & Male & 92 & 3.96 & 0.505 & 0.053 & & \\
\hline & \multirow{2}{*}{$26-35$} & Female & 100 & 4.13 & 0.501 & 0.050 & \multirow[t]{2}{*}{0.156} & \multirow[t]{2}{*}{ NSS } \\
\hline & & Male & 90 & 4.05 & 0.654 & 0.069 & & \\
\hline & \multirow{2}{*}{$36-50$} & Female & 114 & 4.17 & 0.611 & 0.057 & \multirow{2}{*}{$\begin{array}{c}0.033 \\
* *\end{array}$} & \multirow[t]{2}{*}{0.25} \\
\hline & & Male & 124 & 4.03 & 0.520 & 0.052 & & \\
\hline & \multirow{2}{*}{$51-65$} & Female & 92 & 4.06 & 0.636 & 0.066 & \multirow{2}{*}{$\begin{array}{c}0.026 \\
* *\end{array}$} & \multirow[t]{2}{*}{0.28} \\
\hline & & Male & 117 & 3.87 & 0.724 & 0.070 & & \\
\hline & \multirow{2}{*}{$>=66$} & Female & 48 & 4.10 & 0.481 & 0.069 & \multirow[t]{2}{*}{0.398} & \multirow[t]{2}{*}{ NSS } \\
\hline & & Male & 52 & 4.12 & 0.477 & 0.066 & & \\
\hline \multirow{10}{*}{ Perceptions } & \multirow{2}{*}{$<=25$} & Female & 79 & 3.07 & 0.727 & 0.082 & \multirow[t]{2}{*}{0.365} & \multirow[t]{2}{*}{ NSS } \\
\hline & & Male & 92 & 3.03 & 0.794 & 0.083 & & \\
\hline & \multirow{2}{*}{$26-35$} & Female & 100 & 3.02 & 0.762 & 0.076 & \multirow[t]{2}{*}{0.336} & \multirow[t]{2}{*}{ NSS } \\
\hline & & Male & 90 & 3.07 & 0.894 & 0.089 & & \\
\hline & \multirow{2}{*}{$36-50$} & Female & 114 & 3.29 & 0.807 & 0.076 & \multirow{2}{*}{$\begin{array}{c}0.048 \\
* *\end{array}$} & \multirow[t]{2}{*}{0.22} \\
\hline & & Male & 124 & 3.13 & 0.653 & 0.059 & & \\
\hline & \multirow{2}{*}{$51-65$} & Female & 92 & 3.19 & 0.695 & 0.072 & \multirow[t]{2}{*}{0.121} & \multirow[t]{2}{*}{ NSS } \\
\hline & & Male & 117 & 3.08 & 0.671 & 0.062 & & \\
\hline & \multirow{2}{*}{$>=66$} & Female & 48 & 3.25 & 0.589 & 0.085 & \multirow[t]{2}{*}{0.275} & \multirow[t]{2}{*}{ NSS } \\
\hline & & Male & 52 & 3.33 & 0.633 & 0.088 & & \\
\hline
\end{tabular}

Table 7: CSR expectations and perceptions compared by gender and age group.

Statistical significance: ${ }^{*} p$-value $<0.10,{ }^{* *} p$-value $<0.05$, ${ }^{* * *} p$-value $<0.01$ 


\begin{tabular}{|c|c|c|c|c|c|c|c|c|}
\hline CSR Exp./Perc. & $\begin{array}{c}\text { CSR } \\
\text { dimension or } \\
\text { sub-dimension }\end{array}$ & Gender & $N$ & Mean & Std. deviation & Std. error mean & $t$-test p & Cohen's $d$ \\
\hline \multirow{12}{*}{ Expectations } & \multirow{2}{*}{ EC } & Female & 433 & 4.00 & 0.776 & 0.037 & 0.001 & 0.20 \\
\hline & & Male & 475 & 3.84 & 0.831 & 0.038 & $* * *$ & \\
\hline & \multirow{2}{*}{ EN } & Female & 433 & 4.11 & 0.857 & 0.041 & 0.000 & 0.24 \\
\hline & & Male & 475 & 3.90 & 0.914 & 0.042 & $* * *$ & \\
\hline & \multirow{2}{*}{ LA } & Female & 433 & 4.35 & 0.711 & 0.034 & 0.008 & 0.17 \\
\hline & & Male & 475 & 4.23 & 0.701 & 0.032 & $* * *$ & \\
\hline & \multirow{2}{*}{ HR } & Female & 433 & 4.11 & 0.934 & 0.045 & 0.019 & 0.14 \\
\hline & & Male & 475 & 3.97 & 1.004 & 0.048 & $* *$ & \\
\hline & \multirow{2}{*}{ SO } & Female & 433 & 4.07 & 0.779 & 0.037 & 0.004 & 0.19 \\
\hline & & Male & 475 & 3.91 & 0.920 & 0.042 & $* * *$ & \\
\hline & \multirow{2}{*}{ PR } & Female & 433 & 4.11 & 0.720 & 0.035 & 0.041 & 0.12 \\
\hline & & Male & 475 & 4.02 & 0.754 & 0.035 & $* *$ & \\
\hline \multirow{12}{*}{ Perceptions } & \multirow{2}{*}{ EC } & Female & 433 & 3.13 & 0.834 & 0.040 & 0.495 & NSS \\
\hline & & Male & 475 & 3.13 & 0.868 & 0.040 & & \\
\hline & \multirow{2}{*}{ EN } & Female & 433 & 2.89 & 0.927 & 0.045 & 0.033 & 0.12 \\
\hline & & Male & 475 & 2.78 & 0.932 & 0.043 & $* *$ & \\
\hline & \multirow{2}{*}{ LA } & Female & 433 & 3.25 & 0.882 & 0.042 & 0.392 & NSS \\
\hline & & Male & 475 & 3.26 & 0.856 & 0.039 & & \\
\hline & \multirow{2}{*}{ HR } & Female & 433 & 3.14 & 1.062 & 0.051 & 0.113 & NSS \\
\hline & & Male & 475 & 3.05 & 1.120 & 0.051 & & \\
\hline & \multirow{2}{*}{ SO } & Female & 433 & 3.10 & 1.052 & 0.051 & 0.083 & NSS \\
\hline & & Male & 475 & 3.01 & 1.079 & 0.049 & $*$ & \\
\hline & \multirow{2}{*}{ PR } & Female & 433 & 3.44 & 0.917 & 0.044 & 0.179 & NSS \\
\hline & & Male & 475 & 3.39 & 0.898 & 0.041 & & \\
\hline
\end{tabular}

Table 8: CSR expectations and perceptions compared by gender and CSR dimension and sub-dimension. Statistical significance: ${ }^{*}$ p-value $<0.10,{ }^{* *}$-value $<0.05$, ${ }^{* * *}$-v-value $<0.01$ 


\begin{tabular}{|c|c|c|c|c|c|c|c|}
\hline $\begin{array}{c}\text { CSR } \\
\text { dimension or } \\
\text { sub-dimension }\end{array}$ & CSR issue & Gender & Mean & $\begin{array}{c}\text { Std. } \\
\text { deviation }\end{array}$ & $\begin{array}{l}\text { Std. error } \\
\text { Mean }\end{array}$ & $\begin{array}{c}\text { t-test } \\
\mathrm{p}\end{array}$ & Cohen's $d$ \\
\hline \multirow{6}{*}{$\bigcup_{\text {讧 }}^{\cup}$} & \multirow{2}{*}{ Direct economic value } & Female & 4.03 & 1.071 & 0.051 & 0.010 & 0.15 \\
\hline & & Male & 3.86 & 1.174 & 0.054 & $* *$ & \\
\hline & \multirow{2}{*}{ Market presence } & Female & 3.80 & 1.080 & 0.052 & 0.087 & NSS \\
\hline & & Male & 3.71 & 1.056 & 0.048 & $*$ & \\
\hline & \multirow{2}{*}{ Indirect Economic Impacts } & Female & 4.17 & 0.937 & 0.045 & 0.000 & 0.22 \\
\hline & & Male & 3.94 & 1.102 & 0.051 & $* * *$ & \\
\hline \multirow{6}{*}{$\mathrm{Z}_{\mathrm{I}}$} & \multirow{2}{*}{ Materials } & Female & 4.15 & 0.999 & 0.048 & 0.013 & 0.15 \\
\hline & & Male & 4.00 & 1.005 & 0.048 & $* *$ & \\
\hline & \multirow{2}{*}{ Waste } & Female & 4.05 & 1.172 & 0.056 & 0.001 & 0.21 \\
\hline & & Male & 3.79 & 1.262 & 0.058 & $* * *$ & \\
\hline & \multirow{2}{*}{ Compliance } & Female & 4.12 & 1.085 & 0.052 & 0.002 & 0.19 \\
\hline & & Male & 3.90 & 1.185 & 0.054 & $* * *$ & \\
\hline \multirow{8}{*}{ 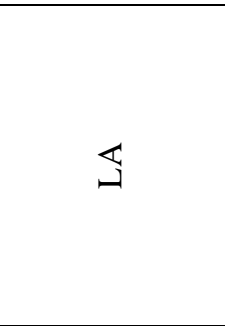 } & \multirow{2}{*}{ Employment } & Female & 4.33 & 1.015 & 0.049 & 0.122 & NSS \\
\hline & & Male & 4.25 & 0.930 & 0.043 & & \\
\hline & \multirow{2}{*}{$\begin{array}{l}\text { Labor/Management } \\
\text { Relations }\end{array}$} & Female & 4.08 & 1.079 & 0.052 & 0.076 & NSS \\
\hline & & Male & 3.97 & 1.100 & 0.050 & $*$ & \\
\hline & \multirow{2}{*}{ Training and Education } & Female & 4.46 & 0.793 & 0.038 & 0.066 & NSS \\
\hline & & Male & 4.38 & 0.862 & 0.040 & $*$ & \\
\hline & \multirow{2}{*}{$\begin{array}{l}\text { Diversity and Equal } \\
\text { Opportunity }\end{array}$} & Female & 4.52 & 0.797 & 0.038 & 0.000 & 0.23 \\
\hline & & Male & 4.32 & 0.930 & 0.043 & $* * *$ & \\
\hline \multirow{4}{*}{ 鿷 } & \multirow{2}{*}{ Non-discrimination } & Female & 4.18 & 1.094 & 0.053 & 0.027 & 0.12 \\
\hline & & Male & 4.04 & 1.187 & 0.054 & $* *$ & \\
\hline & \multirow{2}{*}{$\begin{array}{l}\text { Indigenous Rights and } \\
\text { Local Communities }\end{array}$} & Female & 4.03 & 1.096 & 0.053 & 0.049 & 0.11 \\
\hline & & Male & 3.90 & 1.238 & 0.057 & $* *$ & \\
\hline \multirow{8}{*}{ o } & \multirow{2}{*}{ Corruption } & Female & 4.42 & 0.832 & 0.040 & 0.137 & NSS \\
\hline & & Male & 4.35 & 0.928 & 0.043 & & \\
\hline & \multirow{2}{*}{ Public Policy } & Female & 3.46 & 1.401 & 0.067 & 0.003 & 0.18 \\
\hline & & Male & 3.19 & 1.522 & 0.070 & $* * *$ & \\
\hline & \multirow{2}{*}{ Anti-Competitive Behavior } & Female & 4.16 & 1.033 & 0.050 & 0.019 & 0.14 \\
\hline & & Male & 4.00 & 1.170 & 0.054 & $* *$ & \\
\hline & \multirow{2}{*}{ Compliance } & Female & 4.23 & 1.009 & 0.048 & 0.052 & 0.11 \\
\hline & & Male & 4.11 & 1.144 & 0.052 & $*$ & \\
\hline \multirow{6}{*}{$\frac{\mathfrak{r}}{a}$} & \multirow{2}{*}{ Marketing Communications } & Female & 3.82 & 1.082 & 0.052 & 0.002 & 0.19 \\
\hline & & Male & 3.61 & 1.168 & 0.054 & $* * *$ & \\
\hline & \multirow{2}{*}{ Customer Privacy } & Female & 4.51 & 0.791 & 0.038 & 0.204 & NSS \\
\hline & & Male & 4.46 & 0.832 & 0.038 & & \\
\hline & \multirow{2}{*}{ Compliance } & Female & 4.00 & 1.197 & 0.058 & 0.490 & NSS \\
\hline & & Male & 4.00 & 1.097 & 0.050 & & \\
\hline
\end{tabular}

Table 9: CSR expectations compared by gender and CSR issue.

Statistical significance: ${ }^{*} p$-value $<0.10,{ }^{* *} p$-value $<0.05$, ${ }^{* * *} p$-value $<0.01$ 


\begin{tabular}{|c|c|c|c|c|c|c|c|}
\hline $\begin{array}{c}\text { CSR } \\
\text { dimension or } \\
\text { sub- } \\
\text { dimension }\end{array}$ & CSR issue & Gender & Mean & $\begin{array}{c}\text { Std. } \\
\text { deviation }\end{array}$ & $\begin{array}{l}\text { Std. error } \\
\text { Mean }\end{array}$ & $\begin{array}{c}\text { t-test } \\
\mathrm{p}\end{array}$ & Cohen's $d$ \\
\hline \multirow{6}{*}{$\cup_{[I 1}^{\cup}$} & \multirow{2}{*}{ Direct economic value } & Female & 3.43 & 1.001 & 0.048 & 0.165 & NSS \\
\hline & & Male & 3.50 & 1.056 & 0.048 & & \\
\hline & \multirow{2}{*}{ Market presence } & Female & 2.94 & 1.118 & 0.054 & 0.250 & NSS \\
\hline & & Male & 2.88 & 1.163 & 0.053 & & \\
\hline & \multirow{2}{*}{ Indirect Economic Impacts } & Female & 3.01 & 1.111 & 0.053 & 0.406 & NSS \\
\hline & & Male & 2.99 & 1.150 & 0.053 & & \\
\hline \multirow{6}{*}{ Z } & \multirow{2}{*}{ Materials } & Female & 2.98 & 1.062 & 0.051 & 0.002 & 0.19 \\
\hline & & Male & 2.78 & 1.086 & 0.050 & $* * *$ & \\
\hline & \multirow{2}{*}{ Waste } & Female & 2.69 & 1.281 & 0.062 & 0.073 & NSS \\
\hline & & Male & 2.56 & 1.274 & 0.058 & $*$ & \\
\hline & \multirow{2}{*}{ Compliance } & Female & 3.00 & 1.135 & 0.055 & 0.425 & NSS \\
\hline & & Male & 2.98 & 1.182 & 0.054 & & \\
\hline \multirow{8}{*}{ 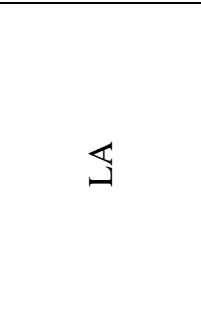 } & \multirow{2}{*}{ Employment } & Female & 3.24 & 1.145 & 0.055 & 0.053 & 0.11 \\
\hline & & Male & 3.11 & 1.164 & 0.054 & $*$ & \\
\hline & \multirow{2}{*}{ Labor/Management Relations } & Female & 3.16 & 1.136 & 0.055 & 0.412 & NSS \\
\hline & & Male & 3.18 & 1.161 & 0.053 & & \\
\hline & \multirow{2}{*}{ Training and Education } & Female & 3.17 & 1.172 & 0.056 & 0.003 & -0.18 \\
\hline & & Male & 3.38 & 1.116 & 0.051 & $* * *$ & \\
\hline & \multirow{2}{*}{ Diversity and Equal Opportunity } & Female & 3.42 & 1.105 & 0.053 & 0.297 & NSS \\
\hline & & Male & 3.38 & 1.127 & 0.052 & & \\
\hline \multirow{4}{*}{ 受 } & \multirow{2}{*}{ Non-discrimination } & Female & 3.12 & 1.183 & 0.057 & 0.457 & NSS \\
\hline & & Male & 3.11 & 1.227 & 0.056 & & \\
\hline & \multirow{2}{*}{$\begin{array}{l}\text { Indigenous Rights and Local } \\
\text { Communities }\end{array}$} & Female & 3.15 & 1.202 & 0.058 & 0.024 & 0.13 \\
\hline & & Male & 2.99 & 1.338 & 0.061 & ** & \\
\hline \multirow{8}{*}{ @ } & \multirow{2}{*}{ Corruption } & Female & 3.18 & 1.270 & 0.061 & 0.277 & NSS \\
\hline & & Male & 3.13 & 1.258 & 0.058 & & \\
\hline & \multirow{2}{*}{ Public Policy } & Female & 2.91 & 1.289 & 0.062 & 0.254 & NSS \\
\hline & & Male & 2.85 & 1.313 & 0.060 & & \\
\hline & \multirow{2}{*}{ Anti-Competitive Behavior } & Female & 3.21 & 1.241 & 0.060 & 0.005 & 0.17 \\
\hline & & Male & 3.00 & 1.252 & 0.057 & $* * *$ & \\
\hline & \multirow{2}{*}{ Compliance } & Female & 3.11 & 1.323 & 0.064 & 0.208 & NSS \\
\hline & & Male & 3.04 & 1.371 & 0.063 & & \\
\hline \multirow{6}{*}{$\underline{a}$} & \multirow{2}{*}{ Marketing Communications } & Female & 3.24 & 1.132 & 0.054 & 0.391 & NSS \\
\hline & & Male & 3.22 & 1.187 & 0.054 & & \\
\hline & \multirow{2}{*}{ Customer Privacy } & Female & 3.69 & 1.207 & 0.058 & 0.275 & NSS \\
\hline & & Male & 3.73 & 1.026 & 0.047 & & \\
\hline & \multirow{2}{*}{ Compliance } & Female & 3.40 & 1.253 & 0.060 & 0.011 & 0.15 \\
\hline & & Male & 3.21 & 1.230 & 0.056 & $* *$ & \\
\hline
\end{tabular}

Table 10: CSR perceptions compared by gender and CSR issue.

Statistical significance: ${ }^{*} p$-value $<0.10$, **p-value $<0.05$, $* * * p$-value $<0.01$ 